\title{
Biosensors Based on Biological Nanostructures
}

\author{
Wendel A. Alves et al.* \\ ${ }^{1}$ Centro de Ciências Naturais e Humanas, Universidade Federal do ABC, Santo André, SP, \\ 'Instituto Nacional de Ciência e Tecnologia de Bioanalítica, Campinas, SP, \\ Brazil
}

\section{Introduction}

The term biomaterials is attributed to the materials employed to medical applications, such as ceramic implants and biopolymer scaffolds, as well as a variety of composites (Hauser e Zhang, 2010). In recent decades, researchers of distinct subjects have gathered efforts in developing new biomaterials for applications in various branches of medicine. With the advent of molecular biology and biotechnology, and knowing that many of these biomaterials are not specific for medical applications, studies have been directed to directed towards to biological and biomimetic materials preparation biological and biomimetic materials (Sanchez, Arribart et al., 2005; He, Duan et al., 2008; Aizenberg e Fratzl, 2009).

In this new class of materials, the peptide compounds appear as promising candidates to building blocks due to their easy preparation and physical and chemical stability (Cheng, Zhu et al., 2007). Thus, we can propose different peptide sequences and from their selforganization to obtain structures with different geometries (spherical, cylindrical, conical) and even nanotubes and/or nanofibers (Hirata, Fujimura et al., 2007) are obtained.

Peptide nanomaterials form supramolecular structures which are interconnected by intermolecular interactions such as van der Waals forces, electrostatic, hydrophobic and hydrogen bonds, among others (Cheng, Zhu et al., 2007; Colombo, Soto et al., 2007). Due to these characteristics, crystal engineering of supramolecular architectures has rapidly expanded in recent years, mainly due to the possibility of intermolecular interactions, structural diversity and potential applications (Sanchez, Arribart et al., 2005; Cheng, Zhu et al., 2007; He, Duan et al., 2008; Aizenberg e Fratzl, 2009). This structural variety is possible due to the planning and construction of supramolecular architectures, as promising building blocks that allow the design of functional molecular materials that will display some sort of ownership of technological interest (Sanchez, Arribart et al., 2005; Cheng, Zhu et al., 2007; He, Duan et al., 2008; Aizenberg e Fratzl, 2009).

The nanostructures obtained from biomolecules are attractive due to their biocompatibility, ability for molecular recognition and ease of chemical modification, important factors on various applications of interest. The functionalization of these materials have greatly

\footnotetext{
* Wellington Alves ${ }^{1,2}$, Camila P. Sousa ${ }^{1,2}$, Sergio Kogikoski. Jr., ${ }^{1,2}$, Rondes F. da Silva1,2, Heliane R. do Amaral $^{1,2}$, Michelle S. Liberato ${ }^{1,2}$, Vani X. Oliveira Jr. ${ }^{1}$, Tatiana D. Martins ${ }^{3}$ and Pedro M. Takahashi ${ }^{4}$ ${ }^{1}$ Centro de Ciências Naturais e Humanas, Universidade Federal do ABC, Santo André, SP, ${ }^{2}$ Instituto Nacional de Ciência e Tecnologia de Bioanalítica,Campinas, SP, ${ }^{3}$ Instituto de Química, Universidade Federal de Goiás, Goiânia, GO, ${ }^{4}$ Departamento de Química, Universidade Federal do Espírito Santo, Vitória, ES, Brazil.
} 
facilitated the study of biological systems, which can be utilized in biosensor devices, catalytic activities and molecular recognition. Thus, the challenge for synthetic chemistry in the area of molecular electronics is to prepare molecules with specific and well defined functions (i.e., that can be used at a molecular level as wires, switches, diodes, etc.). The controlled assemblies of supramolecular species selected components allow the preparation of nanosize materials with quite sophisticated electronic properties (De La Rica e Matsui, 2010).

\subsection{Peptide-based nanostructures}

The formation of tubular peptide nanostructures has been performed using several different peptide sequences, such as heptapeptide $\mathrm{CH}_{3} \mathrm{CO}-\mathrm{Lys}-\mathrm{Leu}-\mathrm{Val}-\mathrm{Ph}-\mathrm{Phe}-\mathrm{Ala}-\mathrm{Glu}-\mathrm{NH}_{2}$, (Lu, Jacob et al., 2003) and dipeptides ${ }^{+} \mathrm{NH}_{3}$-Phg-Phg-COO- (Reches e Gazit, 2004) and ${ }^{+} \mathrm{NH}_{3}-\mathrm{Phe}-$ Trp-COO- (Reches e Gazit, 2003). The first peptide nanotubes were obtained by M.R. Ghadiri and co-workers from cyclic compounds (Ghadiri, Granja et al., 1993). The L-amino acids are the most used building blocks. However, $D$-amino acids can also self-assemble to form nanofibers similar to those obtained from $L$-amino acids (Poteau e Trinquier, 2005).

The properties of peptides can be modified through changes in the sequence of amino acid residues used in their preparation, providing a highly relevant factor in building these new systems (Poteau e Trinquier, 2005). Such changes were reported in a study by varying the $D$ amino acids (D-Alanine, $D$-Leucine and $D$-phenylanine) to obtain different peptide nanotubes (De Santis, Morosetti et al., 2007). It was observed that by employing enantiomers $(\mathrm{D}, \mathrm{L})$ the possibility of obtaining different supramolecular systems arises, with possible changes in their structural and electronic properties (De Santis, Morosetti et al., 2007).

One of the most commonly used peptides in synthesis of nanotubes is ${ }^{+} \mathrm{NH}_{3}$-Phe-Phe-COO.These nanotubes exhibit several unique properties such as high uniformity along the entire length of the tube, biocompatibility, stability against various solvents and thermal stability. In this sense, there are several studies that investigate the structural control of the nanotubes by changing variables such as temperature, solvent and $\mathrm{pH}$ (Adler-Abramovich, Reches et al., 2006). The ${ }^{+} \mathrm{NH}_{3}$-Phe-Phe-COO- nanotubes maintain their morphology up to $200^{\circ} \mathrm{C}$, and total degradation or loss of tubular morphology occurs between 200 and $300^{\circ} \mathrm{C}$ (Ryu e Park, 2010). The thermal stability has been attributed to $\pi$-stacking interactions among aromatic residues that mediate the formation of structures (Reches e Gazit, 2003). The investigation of stability in different organic solvents shows that the nanotubes do not suffer morphological changes after treatment in ethanol, methanol, 2-propanol, acetone and acetonitrile (AdlerAbramovich, Reches et al., 2006).

Moreover, in addition to conformational changes and the sequences of amino acids used in peptide synthesis of nanomaterials, cyclical or linear, the amount of amino acids used and the functional group of the side chains can influence the formation and possibly the desired application (Brea, Castedo et al., 2007). In this case, all the proposed changes and the preparation methods are in early stages of study and require further research to better understand their formation and their influence on structural and electronic properties (Yanlian, Ulung et al., 2009).

\section{Preparation methods of peptide nanostructures}

\subsection{Obtaining nanostructures in liquid phase}

The liquid phase method for obtaining nanostructures is divided in two steps. To obtain a nanostructure based on ( $\left.{ }^{+} \mathrm{NH}_{3}-\mathrm{Phe}-\mathrm{Phe}-\mathrm{COO}-\right)$, for example, the first step is the dissolution 
of the compound in an organic solvent (1,1,1,3,3,3-hexafluoro-2-propanol, HFP) at a concentration of $100 \mathrm{mg} \mathrm{mL}^{-1}$. In the second step, nanostructures are obtained in a spontaneous process, after the dilution in water to achieve $2 \mathrm{mg} \mathrm{mL}^{-1}$ of concentration. By this protocol, ${ }^{+} \mathrm{NH}_{3}$-Phe-Phe-COO- self-assemble as nanotubes of 80 to $300 \mathrm{~nm}$ thick.

The self-assembling mechanism in which nanotubes are produced is not yet fully understood. However, the most acceptable explanation suggests that the $\pi$ - $\pi$ stacking interactions and hydrogen bonds between aromatic rings are responsible for the material nano-organization (Reches e Gazit, 2003).

Another strategy to obtain these materials in liquid phase was proposed by Kim et al. (Kim, Han et al., 2010). In this work, the authors used only pure water as solvent and submitted the system to heating and sonication to dissolve the peptide, since ${ }^{+} \mathrm{NH}_{3}$-Phe-Phe-COOpresent hydrophobic characteristics and do not dissolve easily in water. Nanostructures are formed after cooling $\mathrm{pH}$ values of the preparing media. The concentration of the dipeptide solution was susceptible to variation by the authors in order to comprehend their role in nanostructure formation. Their results showed formation of ${ }^{+} \mathrm{NH}_{3}-\mathrm{Phe}-\mathrm{Phe}-\mathrm{COO}-$ nanowires in alkaline media, while nanotubes were formed in acidic media. Also, at high concentrations of peptide, the predominant nanostructures formed are nanowires, while at low concentrations, nanotubes are prevalent.

\subsection{Nanostructure preparation in solid-vapor phase}

Peptide nanostructures have been prepared by self-assembly oriented in the solid-vapor phase method, which consists of using two solvents, one to solubilize the peptide and another one to encourage the nanostructure assemble. Based on the bottom-up strategy, the first step consists on the formation of a peptide film onto substrate surface (usually silicon), with posterior evaporation of the solvent in the absence of humidity. In this case, the peptide film is referred to as the solid phase. The next step consists of keeping the solid film in a vapor solvent atmosphere, the commonly called vapor phase. Parameters like temperature, vapor pressure, concentration of solid film and exposure time of the film to vapor solvent govern the nanostructure formation.

Ryu et al. described this methodology as the one to obtain 1D nanostructures (Ryu e Park, 2008b; a). The authors studied the influence of temperature and water activity of a solution containing metallic salts in the nanostructures formation and they reported that nanostructures are formed at high water activity, while for activity values lower than 0.3 , no nanostructures were obtained. Also, it was observed that nanostructures were only achieved at a working temperature of 100 to $150{ }^{\circ} \mathrm{C}$. Fig. 1 shows the experimental schematic process to prepare nanowires or nanotubes in solid-vapor phase.

The role of the solvent in this process was adapted by Demirel at al. (Demirel, Malvadkar et al., 2010), with a few adaptations. During this study, the concentration of the precursor solution was controlled at $2 \mathrm{mg} \mathrm{mL}^{-1}$ and the solvent needed at the second step of the solidvapor process was changed. Results show that the nanostructure morphology is related to the dielectric constant values of the solvents. For example, results showed that when formed on water, which presents a dielectric constant of 80.1, a tubular structure is obtained. Same structure are obtained when using methanol ( dielectric constant of 32.6) or ethanol (24.3) as solvents, while solvents presenting dielectric constants much smaller such as toluene (2.4), chloroform (4.8) or tetrahydrofuran (7.5) do not permit the peptide self-assembling and no structure is obtained. Scanning electronic micrographs (SEM) of the nanostructure obtained at various solvents are shown in Fig. 2. 


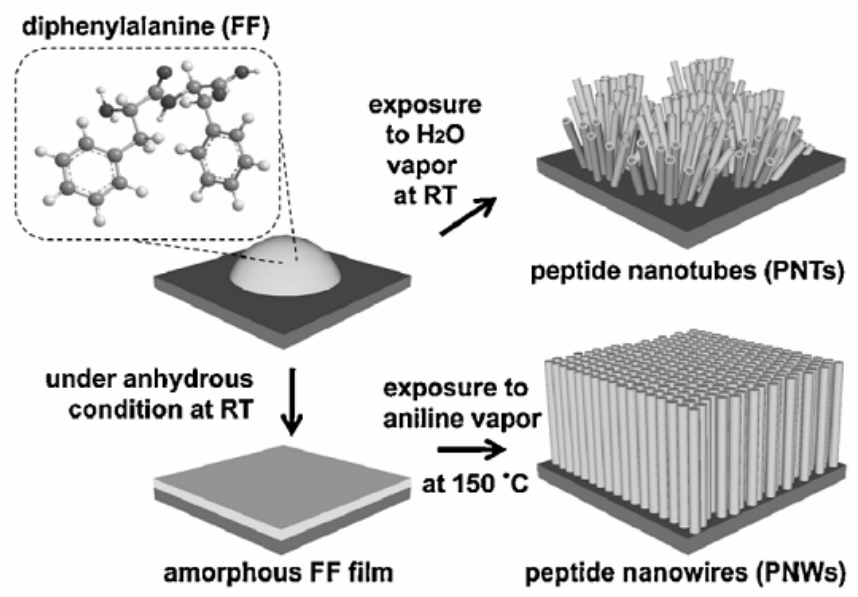

Fig. 1. Experimental scheme of obtaining peptide nanostructure using solid-vapor process. Reprinted with permission from Ryu, J. and C. B. Park (2010). "High Stability of SelfAssembled Peptide Nanowires Against Thermal, Chemical, and Proteolytic Attacks." Biotechnology and Bioengineering 105(2): 221-230 (c) 2010 , Wiley Ltd.
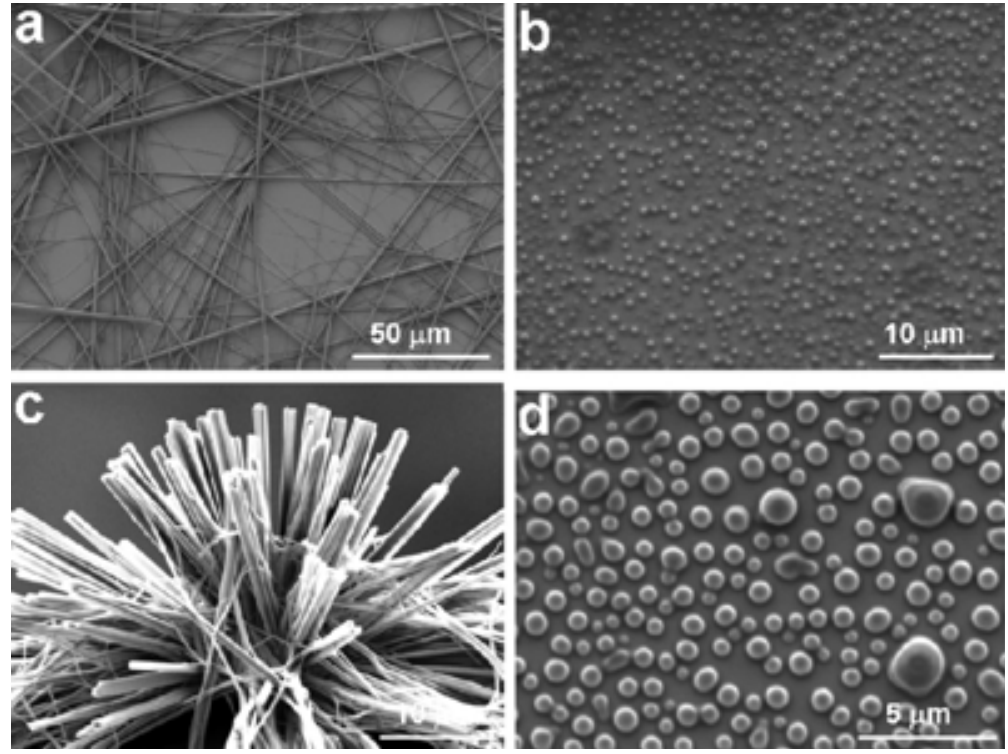

Fig. 2. SEM images of ${ }^{+} \mathrm{NH}_{3}$-Phe-Phe-COO- tubes and vesicles: (a) $2 \mathrm{mg} / \mathrm{mL}$ dipeptide in ethanol vaporized at $25^{\circ} \mathrm{C},(\mathrm{b}) 2 \mathrm{mg} / \mathrm{mL}$ dipeptide in acetone vaporized at $25^{\circ} \mathrm{C}$, (c) $2 \mathrm{mg} / \mathrm{mL}$ dipeptide in ethanol vaporized at $80^{\circ} \mathrm{C}$, and (d) $2 \mathrm{mg} / \mathrm{mL}$ dipeptide in acetone vaporized at $80^{\circ} \mathrm{C}$. Reprinted with permission from Demirel, G., N. Malvadkar, et al. (2010). "Control of Protein Adsorption onto Core-Shell Tubular and Vesicular Structures of Diphenylalanine/ Parylene." Langmuir 26(3): 1460-1463.C 2010 , American Chemical Society Ltd. 


\subsection{Obtaining nanostructures for physical vapor deposition}

Recently, ${ }^{+} \mathrm{NH}_{3}$-Phe-Phe-COO- nanotubes were obtained vertically oriented, employing the physical vapor deposition technique (Fig. 3) (Adler-Abramovich, Aronov et al., 2009). Size and quantity of peptide nanotubes were controlled through deposition parameters adjustment such as time, solvent of preparation, temperature and distance between substrates. The peptide nanotubes formation using this technique became possible because of the low molecular weight and high volatility of precursor species. In a typical synthesis, the ${ }^{+} \mathrm{NH}_{3}-\mathrm{Phe}-\mathrm{Phe}-\mathrm{COO}-$ is heated at $220^{\circ} \mathrm{C}$ in a vacuum chamber containing a clean substrate, heated at $80^{\circ} \mathrm{C}$, that is located at the top of the chamber. The nanotubes formed exhibit length of hundreds of micrometers and diameters of 50 to $300 \mathrm{~nm}$, with morphologies similar to those from the liquid phase. This method has been employed in the fabrication of electronic devices, such as capacitors, but it can be used in the modification of electrodes for electrochemical uses.

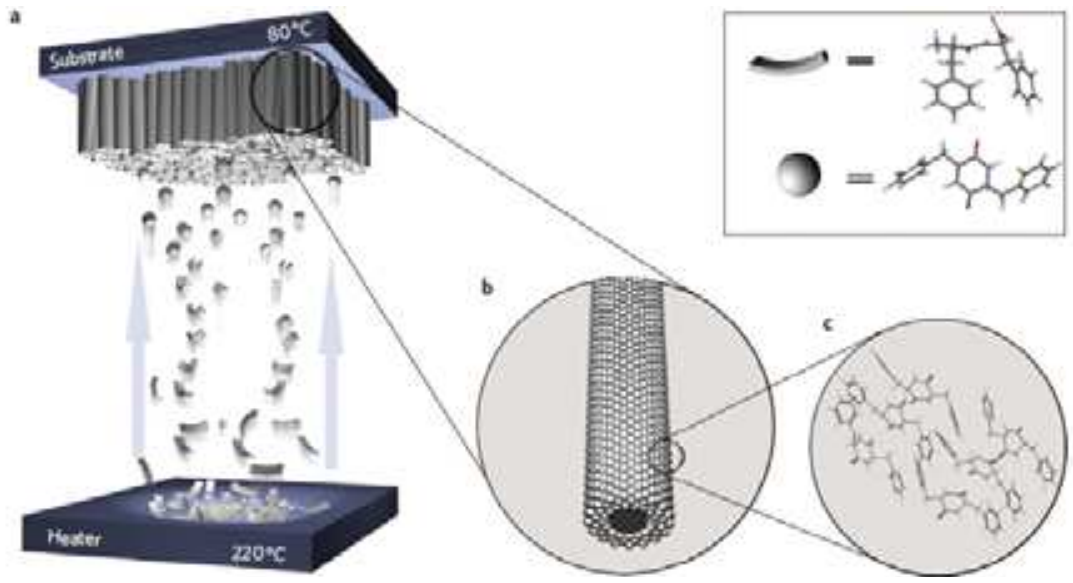

Fig. 3. Proposed assembly mechanism for the formation of vertically aligned ADNTs. (a) Schematic of the vapor deposition technique. During evaporation, the ${ }^{+} \mathrm{NH}_{3}$-Phe-Phe-COOpeptide, which is heated to $220^{\circ} \mathrm{C}$, attained a cyclic structure $\mathrm{Cyclo}\left({ }^{+} \mathrm{NH}_{3}-\mathrm{Phe}-\mathrm{Phe}-\mathrm{COO}-\right)$ and then assembled on a substrate to form ordered vertically aligned nanotubes. (b)Illustration of a single peptide nanotube composed mainly of peptide Cyclo $\left({ }^{+} \mathrm{NH}_{3}\right.$-Phe-Phe-COO- $)$.

(c) Molecular arrangement of six $\mathrm{Cyclo}\left({ }^{+} \mathrm{NH}_{3}-\mathrm{Phe}-\mathrm{Phe}-\mathrm{COO}-\right)$ peptides after energy minimization. A stacking interaction between aromatic moieties of the peptides is suggested to provide the energetic contribution as well as order and directionality for the initial interaction. Reprinted with permission from Shklovsky, J., P. Beker, et al. (2010). "Bioinspired peptide nanotubes: Deposition technology and physical properties." Materials Science and Engineering B-Advanced Functional Solid-State Materials 169(1-3): 62-66. (C) 2009 Elsevier B.V.

In a recently work, this technique was used together with photolithography to enable peptide nanotubes to assume specific positions in a silicon wafer (Shklovsky, Beker et al., 2010). The authors used a photoresist wafer, with square-shaped cavities. The schematic process for the cavities preparation is in Fig. 4. According to SEM images presented in Fig. 4, dipeptide nanotubes are located over the silicon wafer, which is useful to construct integrated circuits, since the orientation and control of nanotubes material size is needed in such systems. 

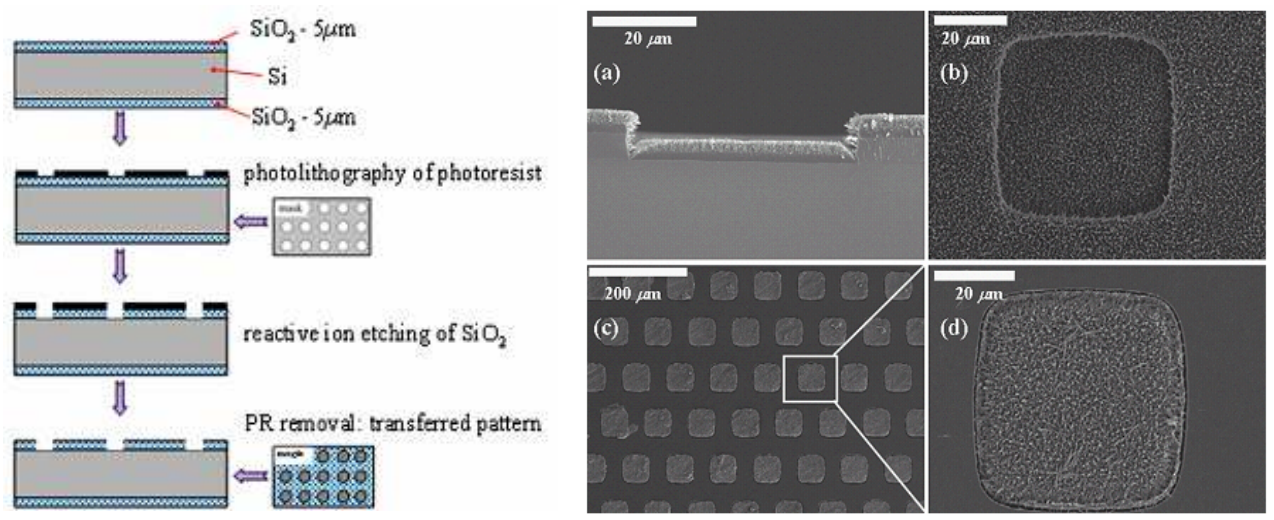

Fig. 4. Left - Schematic diagram of the peptide nanotubes bundles fabrication process. Right - SEM images of patterned arrays of peptide nanotubes fabricated by PVD. (a) Crosssection view of patterned substrate covered by peptide nanotube coating. (b) Top view of patterned substrate covered by peptide nanotube coating. (c) Top view of peptide nanotube bundles after HF release. (d) Enlargement view of image (c) Reprinted with permission from Shklovsky, J., P. Beker, et al. (2010). "Bioinspired peptide nanotubes: Deposition technology and physical properties." Materials Science and Engineering B-Advanced Functional SolidState Materials 169(1-3): 62-66. (c) 2009 Elsevier B.V.

\subsection{Electrospinning}

The electrospinning technique is a technology that uses a high tension electric field $(5-50 \mathrm{kV})$ and low currents $(0.5-1 \mu \mathrm{A})$ to obtain $1 \mathrm{D}$ nanostructures. In this process a fluid material is accelerated and drawn trough an electric field producing structures with reduced diameters. In the work of Singh et al. (Singh, Bittner et al., 2008) ${ }^{+} \mathrm{NH}_{3}-\mathrm{Phe}-\mathrm{Phe}-\mathrm{COO}-$ nanotubes were prepared from solution in HFP. Then, this solution was diluted in water to $2.9 \mathrm{mmol} \mathrm{L}^{-1}$ of concentration and sonicated for 1 hour. Variations in the obtaining parameters of the nanostructures, like electric field, concentration, and flow injection speed on silicon wafer were investigated and their influence on the nanostructure formation was reported.

\section{Functionalization of peptide nanostructures for biosensor applications}

In order to obtain some new properties and increase the applicability of peptide nanomaterials, some chemical modification can be performed and materials can be functionalized to give rise to hybrid compounds. Materials that can be employed on functionalization are nanoparticles, polymers and fluorophores, among others.

Recently, Banerjee et al. reported the synthesis of peptide nanotubes containing bis(N-a-amido-glycylglycine)-1,7-heptane dicarboxylate and its modification with 2-mercaptoethylamine so as to enable its interaction with a Au substrate through a covalent bond. (Banerjee, Yu et al., 2004). In this work, the nanomaterial was deposited on a Gold (Au) substrate modified with a thiol self-assembled monolayer (SAM), containing cavities that could be identified by atomic force microscopy (AFM). AFM images showed that the modification of the substrate by microfabrication techniques became viable due to the 
presence of thiol groups on the outer walls of the nanotubes, which can be covalent attached to the Au substrate, allowing the modification of electrodes in specific positions.

The gold nanoparticles (GNPs) were used to ensure thermal and chemical stability and enzymatic degradation (Guha e Banerjee, 2009). In this work, $\beta$-Ala-L-Xaa (Xaa = Val / Ile / Phe, 1, 2 and 3 respectively), dipeptides were used and studies confirmed that such sequences showed thermal stability up to about $80{ }^{\circ} \mathrm{C}$ and in a wide range of $\mathrm{pH}(2-10)$. Guha and Banerjee have proposed the synthesis of GNPs stabilized by a peptide compound. Their analysis by X-ray diffraction indicated that the nanoparticles formed exhibit a diameter of approximately $7 \mathrm{~nm}$. The influence of $\mathrm{pH}$ and peptide sequence used in the synthesis of the GNP coated peptide nanotubes was also studied, demonstrating that there is a relationship between $\mathrm{pH}$ and GNP coating that leads to a complete and uniform coverage in one specific system, while in other systems the coverage is partial and shapeless. In addition, other parameters were also varied, such as the mass ratio between the GNPs and the peptide nanotube in order to study these interactions ( $\mathrm{pH}$ and GNP coating). Fig. 5 shows transmission electronic microscopy (TEM) images obtained for the peptide nanotubes functionalized with gold nanoparticles.
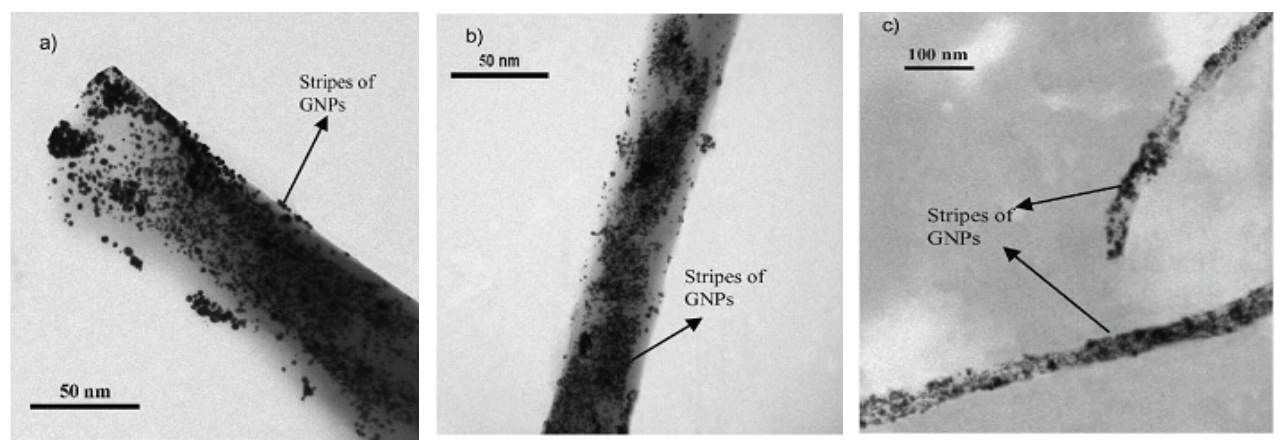

Fig. 5. (a-c) TEM images of dipeptide-capped gold nanoparticles fabricated on the outer surfaces of the dipeptide nanotube 1-3, respectively, at $\mathrm{pH}$ 10. It is clear from the figure that at higher $\mathrm{pH}$ coating of dipeptide-capped GNPs on the outer surfaces of the dipeptide nanotube is more uniform than at lower $\mathrm{pH}$. Reprinted with permission from Guha, S. and A. Banerjee (2009). "Self-Assembled Robust Dipeptide Nanotubes and Fabrication of Dipeptide-Capped Gold Nanoparticles on the Surface of these Nanotubes." Advanced Functional Materials 19(12): 1949-1961.@ 2009 WILEY-VCH Verlag GmbH \& Co. KGaA, Weinheim

In a recent work (Martins et al., 2011 in press), the effect of controlling $\mathrm{pH}$ of nanotube preparation and the concentration of a doping fluorescent molecule on the final structure is carefully studied. Their results showed that structures can vary between nanotubes and nanoribbons, depending on $\mathrm{pH}$ of formation and their growth is influenced by the charge concentration over the nanotubes. Fig. 6 shows SEM and fluorescence microscopy images for nanostructures formed at distinct $\mathrm{pH}$ ranges.

Reches and Gazit studied the formation of peptide nanotubes in a solution containing $\mathrm{Fe}_{3} \mathrm{O}_{4}$ magnetite nanoparticles, , in order to verify the functionalization of peptide nanotubes with magnetic nanoparticles. (Reches e Gazit, 2006). By SEM images the presence of nanoparticles 
onto a surface of peptide nanotube is easily detected. These results suggested that these hybrid systems may find application in sensors and nano(electro) mechanics devices.

$\mathrm{pH}$

3

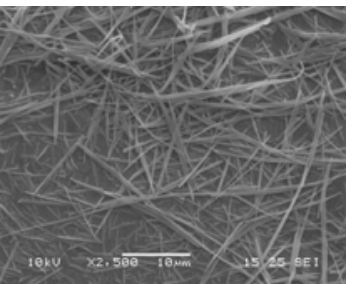

B

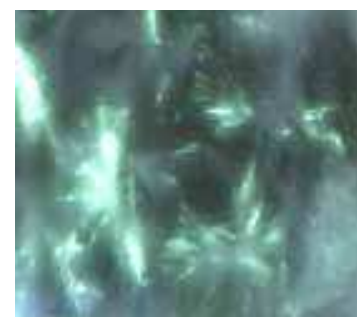

7
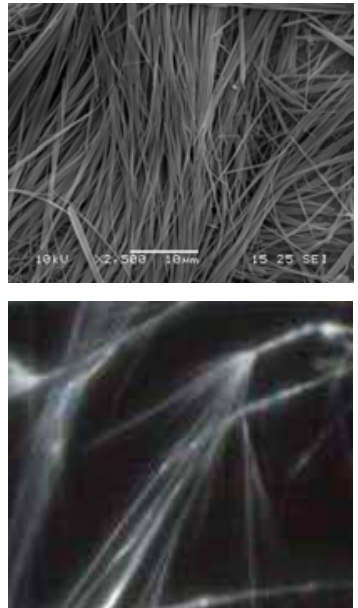

10
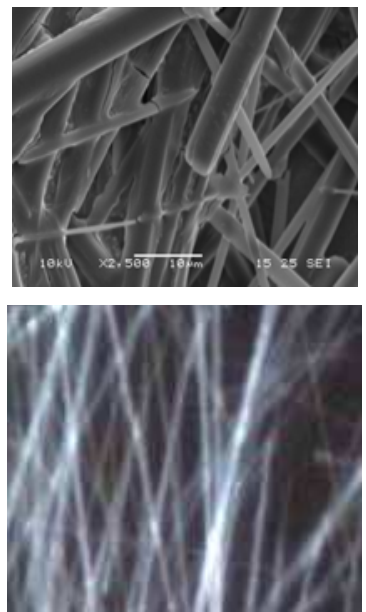

Fig. 6. (a) SEM images for nanotubes formed at the concentration of $0.002 \% \mathrm{~m} / \mathrm{m}$ of pyrenyl moieties, (b) EPM images (200 times increased) for samples of $0.07 \% \mathrm{~m} / \mathrm{m}$ of pyrenyl moieties. All images for samples produced at distinct $\mathrm{pH}$ values.

Functionalized peptide nanostructures based on platinum nanoparticles (PtNPs) were studied by Song et al. (Song, Challa et al., 2004). In this work, nanotubes prepared by selfassembly of ${ }^{+} \mathrm{NH}_{3}$-D-Phe-D-Phe-COO- in solution of distinct concentrations were then functionalized with PtNPs and scanning electron microscopy and Monte Carlo simulations were used to investigate them. Such analyses showed morphological changes related to concentration. At low concentrations, nanotubes were obtained, whereas at high concentrations, nanovesicles were the products. Functionalization was accomplished by adding $\mathrm{K}_{2} \mathrm{PtCl}_{4}$ and ascorbic acid to the solution of peptide nanomaterials. The formation of nanoparticles was verified by the change of solution color. Morphological characterization of nanomaterials functionalized with PtNPs was performed by TEM. These materials can find application in catalysis, among others.

Peptide nanotubes can also be used as support for the growth of semiconductor nanocrystals on the nanotubes surface. (Banerjee, Muniz et al., 2007). According to the authors, it was possible to grow $\mathrm{TiO}_{2}, \mathrm{Ge}$ and $\mathrm{Cu}_{2} \mathrm{~S}$ nanocrystals using this technique. It was also found that a simple change in $\mathrm{pH}$ causes significant differences in crystal size without changing their crystallographic properties.

The peptide nanomaterials can also encapsulate quantum dots (QDs), as reported by Yan and coworkers, in which a ${ }^{+} \mathrm{NH}_{3}-\mathrm{Phe}-\mathrm{Phe}-\mathrm{COO}-$ hydrogel is treated as three-dimensional and interconnected nano-scaled fibers, that are used in the encapsulation of QDs. (Yan, Cui et al., 2008). Results indicate the promising employment of such materials in nano- and biotechnology. 
a)
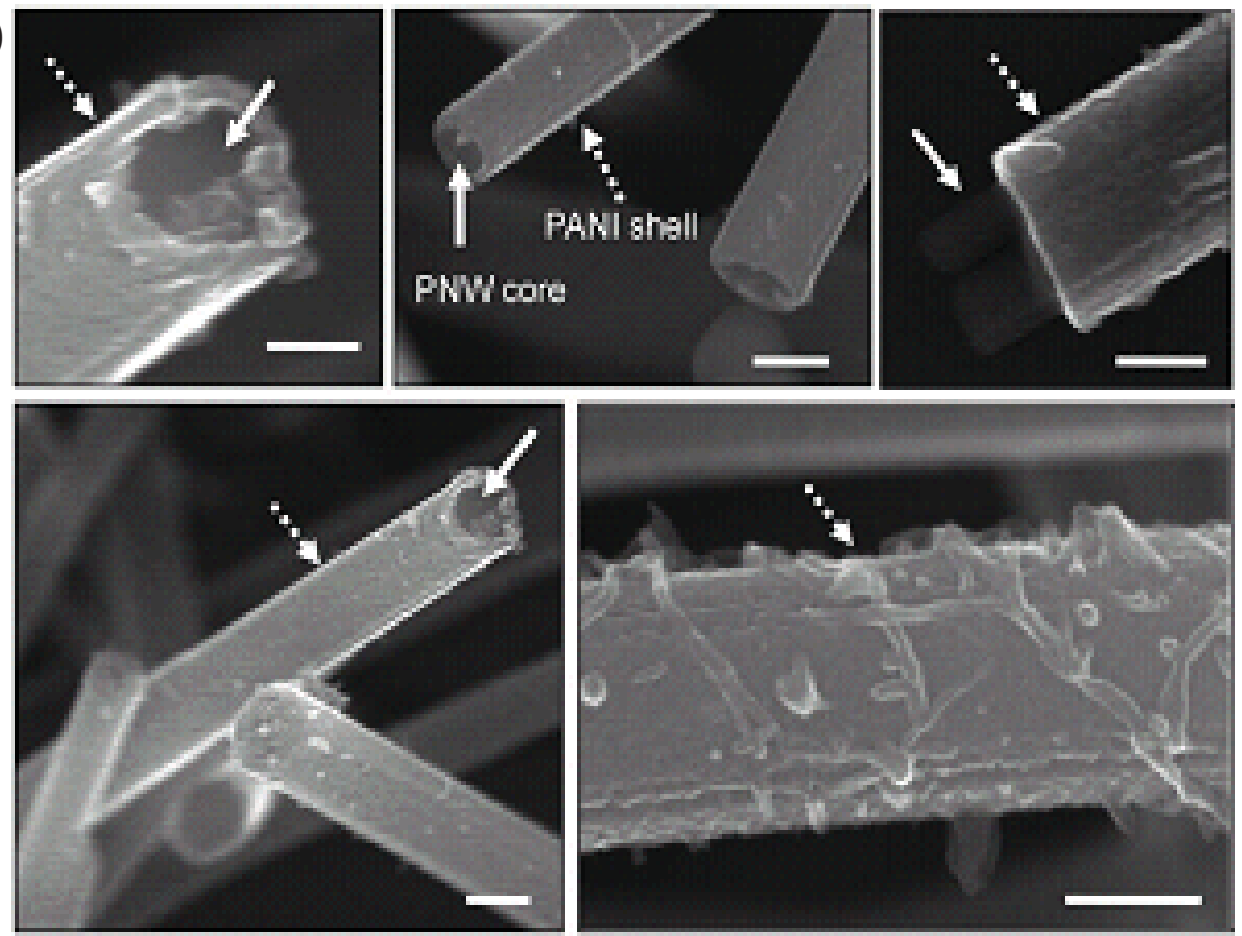

b)
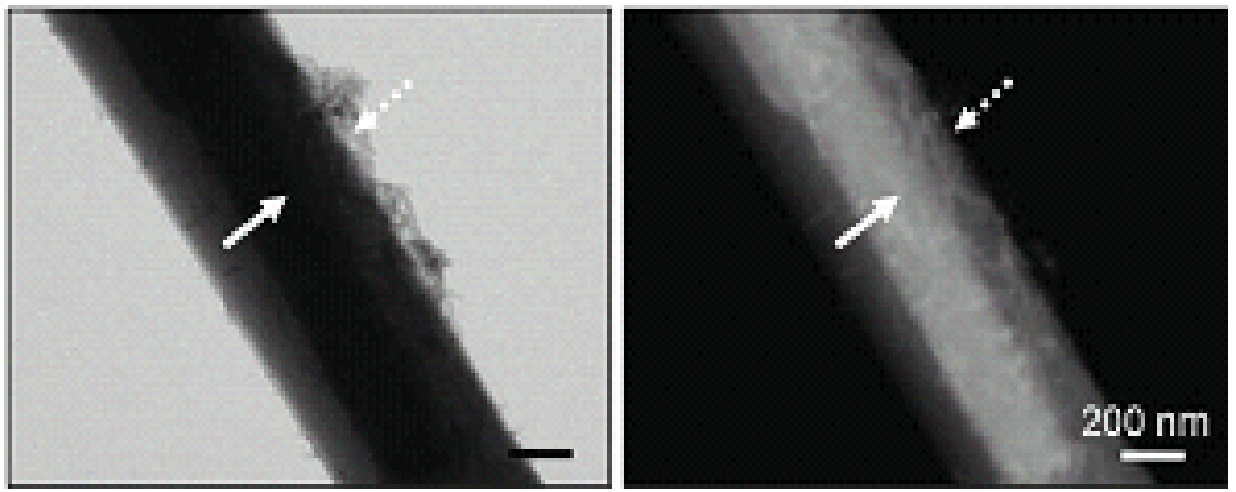

Fig. 7. (a) SEM and (b) STEM images of PNW/PANI core/shell nano- wires. Arrows indicate the PNW core (solid arrows) and PANI shell (dotted arrows). The core/shell structure of the PNW/PANI nanowires was clearly visible in STEM micrographs taken in a bright field imaging mode (left) and in a high angle angular dark field imaging mode (right). Reprinted with permission from Ryu, J. and C. B. Park (2009). "Synthesis of Diphenylalanine/Polyaniline Core/Shell Conducting Nanowires by Peptide SelfAssembly." Angewandte Chemie-International Edition 48(26): 4820-4823. (C) 2009 Wiley-VCH Verlag GmbH \& Co. KGaA, Weinheim 
The obtaining of core-shell structures between peptide nanowires (PNWs) and polyaniline (PANI) was also reported (Ryu e Park, 2009). Vertically oriented nanowires were formed by using the solid-vapor method. The nanowires were submitted to chemical modification using a polymerizing solution of ammonium persulfate (APS) containing aniline and $\mathrm{HCl}$ $(1 \mathrm{M})$ to generate the PANI shell along the sidewall of the PNWs. The SEM and scanning transmission electron microscopy (STEM) images in Fig. 7 show the presence of PANI on the nanowires. PNWs core was removed with 1,1,1,3,3,3-hexafluoride-2-propanol (HFIP). This material cam be applied as a biosensor in the detection of volatile organic compounds, glucose and hydrogen peroxide.

\section{Peptide nanomaterials in biosensors}

Since the Clark electrode (Clark, Wolf et al., 1953), a remarkable progress has been made on the development of biosensors for clinical analyses (Yoo e Lee, 2010). A biosensor is an integrated receptor-transducer device, which is capable of providing selective quantitative or semi-quantitative analytical information using a biological recognition element (Thevenot, Toth et al., 1999). This chapter will emphasize the use of peptide nanomaterials on development of electrochemical, optical and piezoelectric biosensors.

\subsection{Electrochemical biosensors}

Electrochemical biosensors are currently among the most popular of several types of biosensors. Particularly, carbon nanotubes (CNTs) are excellent materials for the development of biosensors (Wang e Lin, 2008), since they exhibit properties which improve the electron transfer reaction and increase the electrochemical reactivity of enzymatic products. However, CNTs are often produced using expensive techniques such as chemical vapor deposition (CVD). Such instruments usually need large-scale consumption and higher production costs. Recently, the use of peptides has attracted the attention of material science researchers. This is attributed to the biocompatibility and molecular recognition of peptides with other (bio)molecules or cells, resulting in many novel polymer-peptide hybrid molecules as surface modifiers for implants or tissue engineering applications (De La Rica e Matsui, 2010).

Electrochemical methods of analysis were first applied to peptide nanotubes by Yemini et al. In 2005. Cyclic voltammetry measurements revealed the presence of well-defined, reversible anodic and cathodic peaks indicated improved electrochemical reactivity for the potassium hexacyanoferrate with ${ }^{+} \mathrm{NH}_{3}$-Phe-Phe-COO- nanotube-modified electrode. The effect of the nanotube deposition on the electrochemical process has also been investigated using chronoamperometric measurements by application of a potential of $+200 \mathrm{mV} v s$. $\mathrm{Ag} / \mathrm{AgCl}$ under continuous stirring of the solution and successive additions of $\mathrm{K}_{4} \mathrm{Fe}(\mathrm{CN})_{6}$. In this case, the modified electrode has shown significant higher signal (about 2.5-fold increase) as compared to the nonmodified electrode. The increase of current can be attributed to the high electroactive surface area. The authors also explored the detection potential of peptide nanotube-modified electrodes for measuring hydrogen peroxide in phosphate buffer solution, using peroxidase and 4-acetaminophenol as mediators by applying a potential of $50 \mathrm{mV}$. The variation of the cathodic current corresponds to quinine (NAPQI) reduction, allowing indirect detection of hydrogen peroxide in solution (Sima, Cristea et al., 2008). The current obtained by the modified ${ }^{+} \mathrm{NH}_{3}$-Phe-Phe-COO- nanotubes electrode was four times 
higher than that obtained for the non-modified electrode, which is related to the increase of the functional electrode as previously suggested for CNT, which was evidenced by degradation of the nanostructures by proteinase-K on the electrode surface.

These nanotubes were further used in the construction of amperometric sensors for detection of $\beta$-nicotinamide adenine dinucleotide $(\mathrm{NADH})$, hydrogen peroxide and ethanol in the absence of redox mediator (Yemini, Reches, Gazit et al., 2005). In this case, the ${ }^{+} \mathrm{NH}_{3}$-Phe-Phe-COO- nanotubes were used to modify a gold disk electrode surface by the self-assembly process, by using Traut's reagent (2-iminothiolane hydrochloride). The cyclic voltammetry of modified electrode in solution containing $\mathrm{NADH}$ has shown a significant increase in the sensitivity of the electrode (Fig. 8). The peptide nanotubemodified electrode responded significantly and rapidly to the changes in NADH concentration, as observed by amperometric measurement at $+0.4 \mathrm{~V}$, producing steadystate signals within less than $5 \mathrm{~s}$.
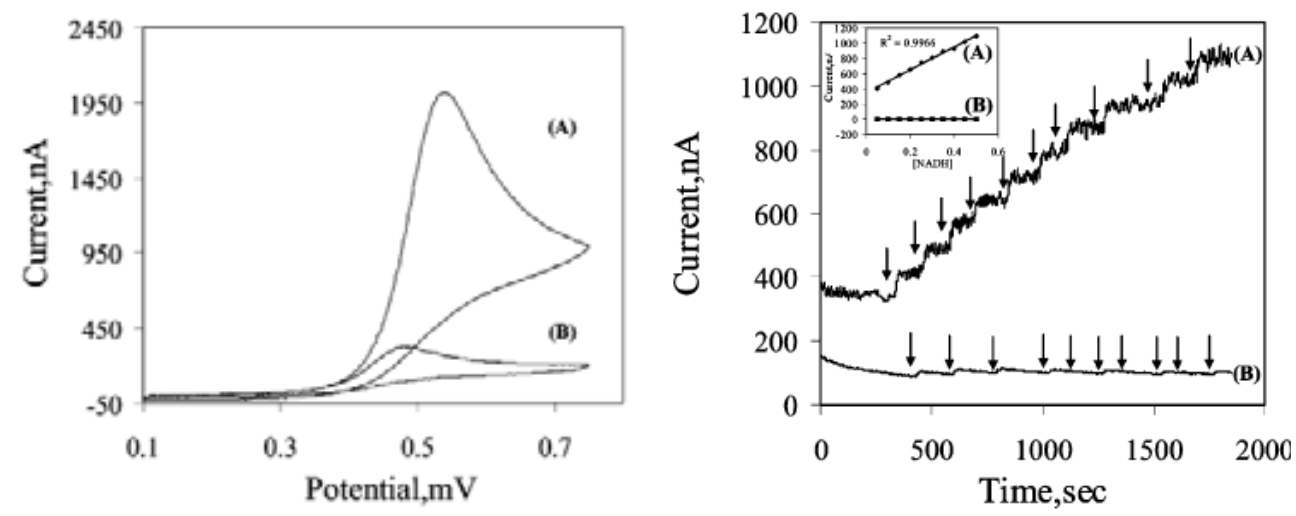

Fig. 8. Direct measurement of NADH on the peptide nanotube-based electrode. (Left) Cyclic voltammetry of (A) peptide nanotube-based electrode; (B) unmodified electrode measured in a solution containing $50 \mathrm{mM}$ NADH. Scan rate, $50 \mathrm{mV} / \mathrm{s}$. (Right) Amperometric response to successive additions of $50 \mu \mathrm{M}$ NADH. at $+0.4 \mathrm{~V}$ vs. SCE. (A) Peptide nanotube-based electrode; (B) bare electrode. Arrows indicate the addition of increasing concentrations of NADH. Reprinted with permission from Yemini, M., M. Reches, et al. (2005). "Peptide nanotube-modified electrodes for enzyme-biosensor applications." Analytical Chemistry 77(16): 5155-5159.@2005 American Chemistry Society

In developing a biosensor for glucose, Yemini and co-workers promoted the modification of the peptide nanotube-based gold electrode with glucose oxidase in presence of glutaraldehyde and PEI (polyethyleneimine). The detection mechanism is based on the determination of glucose by monitoring the hydrogen peroxide, which is produced by an enzymatic reaction between glucose oxidase, covalently linked to peptide nanotubes by glutaraldehyde on the gold electrode surface (Yemini, Reches, Gazit et al., 2005). Among the applications, this biosensor can be used to detect glucose in urine and blood for the diagnosis of diabetes and also to monitor the amount of glucose during fermentation processes in food industry (Wang, 2008). 
A

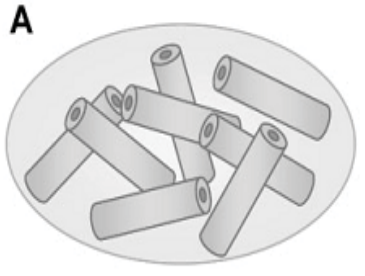

Nanotubes

B

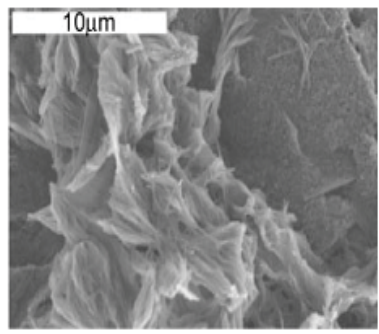

C

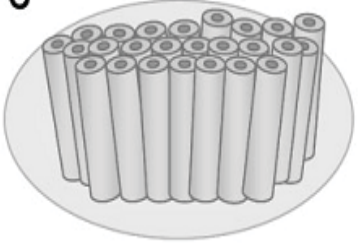

Nanoforest

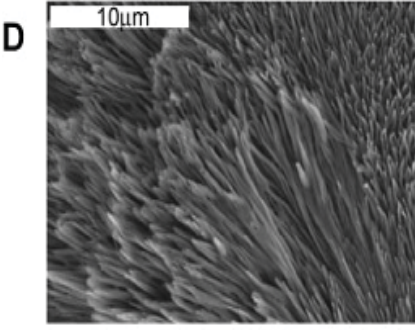

E

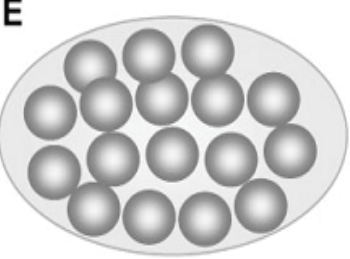

Nanospheres
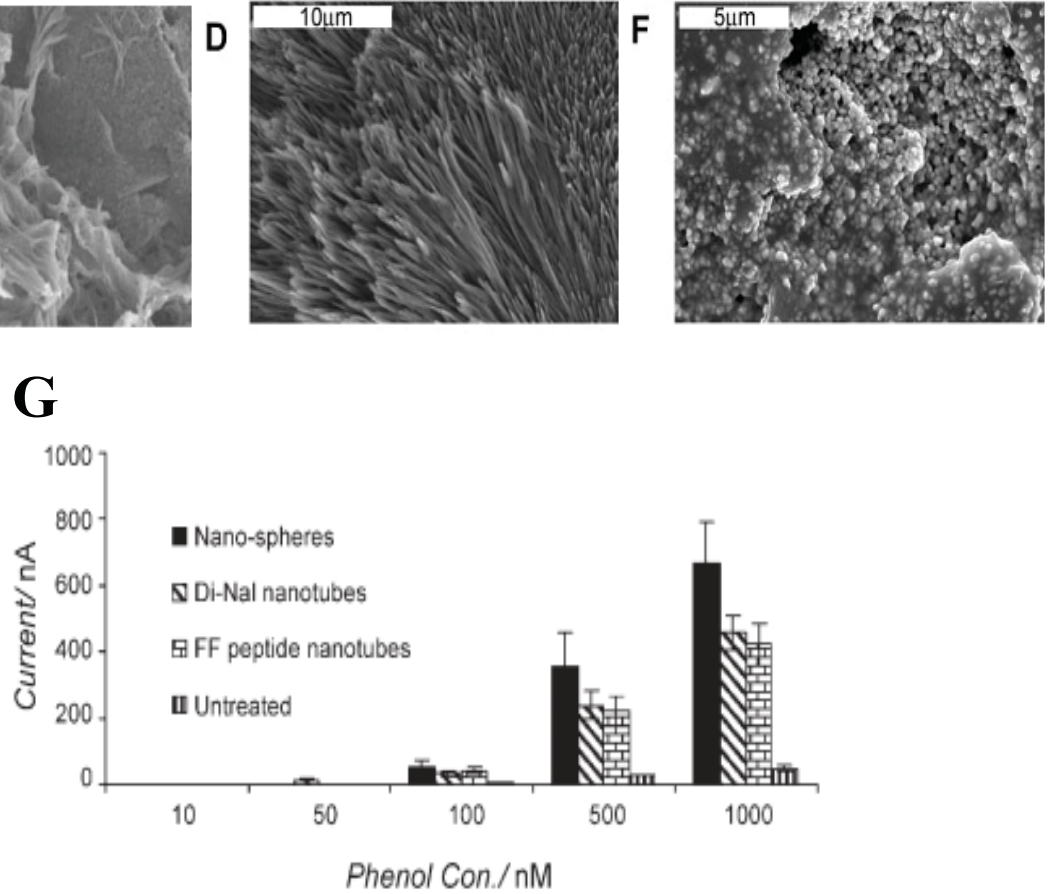

Fig. 9. Various nanoassemblies deposited on a screen-printed electrode. $(a, b)+\mathrm{NH}_{3}-\mathrm{Nal}-\mathrm{Nal}-$ $\mathrm{COO}^{-}$nanotubes deposited on an electrode, illustration and SEM image, respectively. $(\mathrm{c}, \mathrm{d})+\mathrm{NH}_{3}$-Phe-Phe-COO- peptide nanoforest deposited on an electrode, illustration and SEM image, respectively. (e,f) Boc-Phe-Phe-OH peptide nanospheres deposited on an electrode, illustration and SEM image, respectively. (g) Amperometric response of untreated, ${ }^{+} \mathrm{NH}_{3}$-Phe-Phe-COO- nanotubes, ${ }^{+} \mathrm{NH}_{3}-\mathrm{Nal}-\mathrm{Nal}-\mathrm{COO}-$ nanotubes, and Boc-PhePhe-OH peptide nanospheres on screen-printed modified electrodes to different phenol concentrations in $0.1 \mathrm{M}$ phosphate buffer, $0.1 \mathrm{M} \mathrm{KCl}(\mathrm{pH} 7.4)$. Measurements were performed at $\# 100 \mathrm{mV}$ working potential versus $\mathrm{Ag} / \mathrm{AgC}$ (Adler-Abramovich, Badihi-Mossberg et al., 2010) Reprinted with permission from Adler-Abramovich, L., M. Badihi-Mossberg, et al. (2010). "Characterization of Peptide-Nanostructure-Modified Electrodes and Their Application for Ultrasensitive Environmental Monitoring." Small 6(7): 825-831.@ 2010 WileyVCH Verlag GmbH \& Co. KGaA, Weinheim 
Recently, Adler-Abramovich and co-workers have studied the electrochemical characterization of ${ }^{+} \mathrm{NH}_{3}$-Phe-Phe-COO- nanotubes-modified graphite electrodes and compared them to the CNT-based sensor. After that, the enzyme tyrosinase was immobilized on these nanostructure-modified electrodes for phenol detection. Various methodologies for the pattern deposition of aromatic dipeptide nanotubes and their horizontal and vertical alignment were also tested (Adler-Abramovich, Badihi-Mossberg et al., 2010). For such experiment, the authors used ${ }^{+} \mathrm{NH}_{3}-\mathrm{Phe}-\mathrm{Phe}-\mathrm{COO}-$ nanotubes, naphthylalanil-naphthylalanine $\left({ }^{+} \mathrm{NH}_{3}-\mathrm{Nal}-\mathrm{Nal}-\mathrm{COO}-\right)$ nanotubes, ${ }^{+} \mathrm{NH}_{3}$-Phe-Phe-COOnanoforests and tert-butoxicarbonil-Phe-Phe-OH (Boc-Phe-Phe-OH) nanospheres (Fig. 9). In this case, the tubular nanostructures have similar sensitivities, while the nanospheres show sensitivity 14 times higher compared to the untreated electrode. The electrodes modified with nanoforests showed sensitivity 17 times greater than the untreated electrode (Fig. 8). These results have been explained by the augment of the active area of the electrodes, which was confirmed by Randles-Sevcik equation. The area calculated for the bare electrode was $0.02 \mathrm{~cm}^{2}$. After coating it with either ${ }^{+} \mathrm{NH}_{3}-\mathrm{Phe}-\mathrm{Phe}-\mathrm{COO}-$ or ${ }^{+} \mathrm{NH}_{3}-\mathrm{Nal}-\mathrm{Nal}-\mathrm{COO}-$ nanotubes, the surface area of the electrode was similar $\left(0.05 \mathrm{~cm}^{2}\right)$. Peptide-nanosphere modification increased the surface area to $0.06 \mathrm{~cm}^{2}$. The highest surface area, $0.07 \mathrm{~cm} 2$, was obtained on the electrode coated with the nanoforest. Thus, the presence of the ${ }^{+} \mathrm{NH}_{3}-\mathrm{Phe}-$ Phe-COO- nanoforests significantly improves the sensitivity of the biosensor by increasing the surface area of the electrode and inducing electron transfer in the chemical reaction.

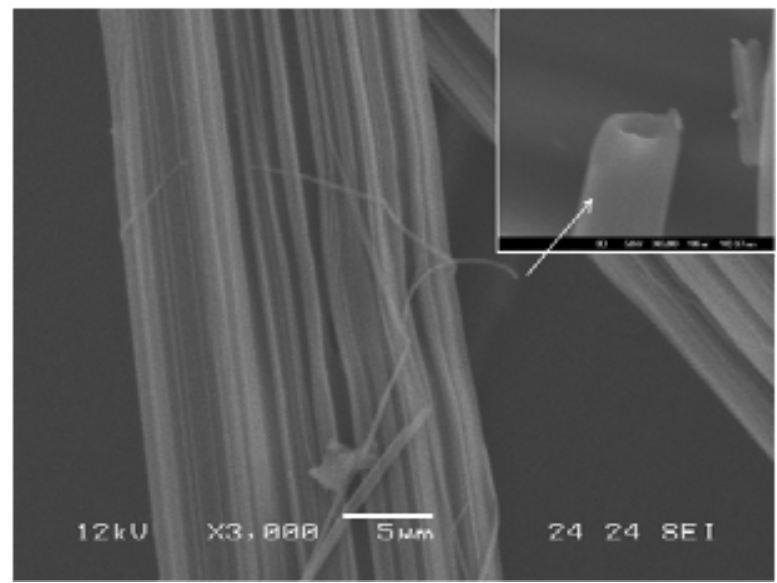

Fig. 10. SEM images showing stability of the diphenylalanine peptide nanotubes prepared in $\mathrm{pH} 7$ solution containing microperoxidase-11 intercalated among the different hexagonal layers of such nanotubes. Reprinted with permission from Cipriano, T. C., P. M. Takahashi, et al. (2010). "Spatial organization of peptide nanotubes for electrochemical devices." Journal of Materials Science 45(18): 5101-5108. (C) Springer Science Business Media, LLC 2010

A novel biosensor for hydrogen peroxide was recently developed by combining the known properties of microperoxidase-11 (MP11) as an oxidation catalyst and the interesting properties of ${ }^{+} \mathrm{NH}_{3}$-Phe-Phe-COO- nanotubes (PNTs) as a supporting matrix, Fig. 10, in order to allow a good bioelectrochemical interface (Cipriano, Takahashi et al., 2010). In this case, the synthesized MP11/PNTs were immobilized onto the ITO electrode surface via 
Layer-by-Layer (LBL) deposition, using poly(allylamine hydrochloride) (PAH) as positively charged polyelectrolyte layers. The PNTs provided a favorable microenvironment for MP11 to perform direct electron transfer to the electrode surface. The resulting electrodes showed a pair of well-defined redox peaks with formal potential at about $-343 \mathrm{mV}$ (versus SCE) in phosphate buffer solution ( $\mathrm{pH} 7$ ). The experimental results also demonstrated that the resulting biosensor exhibited good electrocatalytic activity to the reduction of $\mathrm{H}_{2} \mathrm{O}_{2}$ with a sensitivity of $9.43 \mu \mathrm{A} \mathrm{cm}^{-2} \mathrm{mmol}^{-1} \mathrm{~L}$, and a detection limit of $6 \mu \mathrm{mol} \mathrm{L}^{-1}$ at the signal-to-noise ratio of 3 . These values are expressive when compared with other procedures that involve immobilization of MP11 onto electrode surfaces that have already been reported in literature (Cipriano, Takahashi et al., 2010). These values demonstrate that the PNTs can provide a bridge of electron transfer between protein and electrode. The high value obtained for the detection limit of such analyte can be related to the isolating characteristic of this material, due to wide semiconductor-like band gaps when compared to other semiconductor-like organic molecules. Moreover, we also observed that the peptides self-assembly can be influenced during the change of the $\mathrm{pH}$ of the solution. The study proved that the combination of PNTs with MP11 is able to open new opportunities for the design of enzymatic biosensors with potential applications in practice.

Yang and co-workers have proposed a novel approach using ionic-complementary peptides (EAK16-II) to modify a highly ordered pyrolytic graphite electrode and enhance its compatibility with enzymes for biosensor applications. The GOx was covalently immobilized on the peptide nanofiber matrix through amide bond formation between the amine groups on GOx and the carboxylate groups of glutamic acid residues on the peptide. Its catalytic activity for glucose oxidation is measured using ferrocenecarboxylic acid (FCA) as a mediator for electron transduction. The sensitivity was found to be $26 \mathrm{nA} \mathrm{mmol}-1 \mathrm{~L} \mathrm{~mm}^{-}$ 2, which is more than 6 times higher than that obtained with GOx on thiol-modified gold nanotubes and gold electrodes $\left(\sim 4 \mathrm{nA} \mathrm{mmol}-1 \mathrm{~L} \mathrm{~mm}^{-2}\right)$ (Yang, Fung et al., 2009). More recently, metalized peptide nanowires have been employed as conduits for electronic signals between a redox enzyme (NADH peroxidase) and a carbon-nanotube electrode to enhance detection sensitivity (Yeh, Lazareck et al., 2007).

Another application of peptide nanotubes involves the fabrication of electrochemical immunosensors. In this case, the cyclic peptide (cyclo[(Gln-D-Leu $\left.)_{4}\right]$ ) was used for the formation of nanotubes, which was later immobilized onto a substrate of carbon paste (Cho, Choi et al., 2008). After that, the immobilization of antibody anti-E. coli O157:H7 was carried out onto the surface of the tubes. This immobilization is possible due to the bond formed between the carboxylic group present in the surface of the nanotubes and the amine groups present in the enzyme structure. This immobilization was confirmed by fluorescence microscopy images, showing the functionalization of the surface with the antibody. The antigen-antibody interaction onto the surface of the electrode modified with nanotubes was confirmed by SEM (Fig. 11) and electrochemical studies, indicating potential applications in the development of electrochemical immunosensors for detection of pathologies such as $E$. coli.

De la Rica and co-workers reported a significant improvement in the electrochemical behavior of pathogen sensors using peptide nanotubes for sensor-chip fabrication. In this work, bola-amphiphilic peptide monomers self-assembly to form peptide nanotubes and then, they were coated by antibodies in a simple incubation process (De La Rica, Mendoza et al., 2008). Pathogen detection is achieved due to the difference in the dielectric properties of viral particles and water molecules. Hence, binding viruses to the peptide nanotubes 
decreases the permittivity of the medium surrounding the nanotube and, consequently, decreases the capacitance between electrodes. In this device configuration, the major role of the nanotubes is to concentrate targeted viruses selectively by molecular recognition at this location. At this position, impedimetric detection with the electrodes is most sensitive (De La Rica, Mendoza et al., 2008).

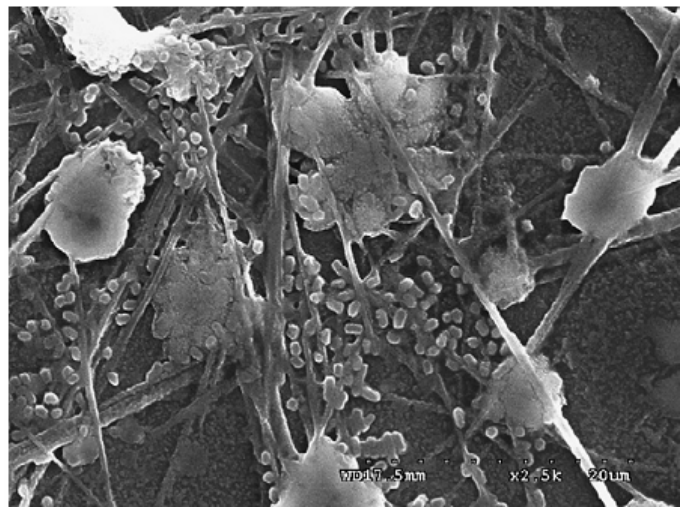

Fig. 11. SEM Image of attaching E. coli O157:H7 cells on the surface of peptide nanotubes by antigen-antibody interaction. Reprinted with permission from Cho, E. C., J. W. Choi, et al. (2008). "Fabrication of an electrochemical immunosensor with self-assembled peptide nanotubes." Colloids and Surfaces a-Physicochemical and Engineering Aspects 313: 95-99 (c) 2007 Elsevier B.V.

In another approach, membranes for dynamic sensors of ions were obtain throught the selfassembled nanotubes vertically aligned under the substrate. Motesharei et al. verified that peptide nanotubes provide channels for ion selection due to their hydrophobic character and the possibility of orientation during immobilization on the gold substrate through thiol monolayers (Motesharei Ghadiri, 1997). These channels were obtained from peptide nanotubes synthesized using D-Leu and L-Trp aminoacids (Hartgerink, Granja et al., 1996). The immobilization of nanotubes onto gold substrate was oriented by thiol monolayers in two methodologies. The first methodology consisted of immersing gold substrate in an ethanolic solution containing either 1-dodecanethiol or dodecyl sulfide for 12 hours. After the formation of the monolayer, the electrode was washed with ethanol, dried in $\mathrm{N}_{2}$ gas and immersed in an ethanolic solution $\left(0.1 \mathrm{mmol} \mathrm{L}^{-1}\right)$ of cyclic peptide for 12 hours. In the second methodology the gold substrate was immersed in an ethanolic solution composed of 10 mmol L-1 of 1-dodecanethiol or dodecyl sulfide and cyclic peptide $\left(0.1 \mathrm{mmol} \mathrm{L}^{-1}\right)$ during 12 hours. After the formation of the monolayer, the electrode was washed using ethanol, and dried in Ar.

The orientation of self-assembled cyclic peptides was verified by grazing angle FTIR spectroscopy through the band absorption of amide group compared to the band related to the N-H stretching. Such comparison is justified based on the attenuation of the stretching $\mathrm{N}-\mathrm{H}$ bond caused by the presence of gold onto the horizontally-oriented nanotube.

FTIR analysis showed that both substrates modified by methodology 1, using thiol and thioether, presented greater amount of peptide tubular structures perpendicular to substrate due high intensity in peak at $1635 \mathrm{~cm}^{-1}$, attributed to amine groups. The lower intense peaks 
at $1686 \mathrm{~cm}^{-1}$ and $1549 \mathrm{~cm}^{-1}$ were assigned to amine groups parallel to substrate. Substrate treated by methodology 2 exhibits parallel and perpendicular alignment to substrate. Orientation mixture occurred due adsorption competition between thiol and tubular structure onto surface of gold. Therefore, the stability obtained on thiol allowed the alignment of structures. The application for ion selective channel of peptide layers was verified by cyclic voltammetry, employing three electroactive species: $\left[\mathrm{Fe}(\mathrm{CN})_{6}\right]^{3-}$, $\left[\mathrm{Ru}\left(\mathrm{NH}_{3}\right)_{6}\right]^{3+}$ and $\left[\mathrm{Mo}(\mathrm{CN})_{8}\right]^{4-}$. The electrodes prepared by methodology 2 presented good activity for less electroactive species: $\left[\mathrm{Fe}(\mathrm{CN})_{6}\right]^{3-}$ and $\left[\mathrm{Ru}\left(\mathrm{NH}_{3}\right)_{6}\right]^{3+}$.

\subsection{Optical sensors}

Optical biosensing techniques have been widely developed because of their potential applications in a number of fields such as health care, food industry, environment monitoring and protection and in the nanotechnology field. Many are the approaches that use optical biosensor investigation techniques such as colorimetric absorbance biosensors (Song, Cheng et al., 2002), which are also commercially available and conjugated polymerbased biosensors (Wang, Wang et al., 2000).

Among the large variety of transducing principles that have been developed, as those mentioned in section 4.1, fluorescence-based detection has attracted the scientific community attention.

\subsubsection{Fluorescence-based biosensors}

Due to a number of advantages that includes high sensitivity, non-destructive characteristics of most techniques of measurements, simplicity of sensor construction and diversity of fluorescence parameters that can provide sensing properties, in this decade, fluorescencebased biosensors have been greatly exploited and developed. Their function is based on the evaluation of the optical response disturbs of a well-know fluorophore attached to or doped into the system, caused by its interaction with local constituents of the system. In the simplest sensor, the fluorophore shows binding affinity for a particular target in the system, but sometimes, more than one fluorophore incorporated at distinct locations are used in the sensor construction. (Marvin, Corcoran et al., 1997) In any case, the use of fluorescent properties to sensing applications is general and versatile, but there are some requirements for the construction of the fluorescent recognition unit, such as the fluorophore structure and its photophysical mechanisms of response and the fluorescence parameters that will be determinant in detection, since in sensing applications, detection is based on a variation in fluorescence properties of a molecular recognition unit that occurs when it interacts with the target to be detected (Mcfarland e Finney, 2001).

A very interesting advantage of the use of fluorescence response on biosensor is that sensing can be achieved by using associated transduction strategies (Altschuh, Oncul et al., 2006). It is well known that fluorescence properties of any dye, enclosed in an environment to which it can interact, are altered in response to those interactions (Birks, 1970; Lakowicz, 1999). Therefore, fluorescent dyes, or fluorophores, are said to be environmentally sensitive and thus, they can provide signal transduction. In the cases in which it is possible to have the fluorophore coupled to a certain region of a receptor near its binding site which can suffer a conformational change upon ligand approximation, its environment and thus its fluorescence properties change on complex formation (De Lorimier, Smith et al., 2002) leading to an optical response that is related to the identity of the ligand or to the nature of 
interactions and to the quantity of such ligand. These characteristics make fluorescence the most sensitive of all existing methods to detect intermolecular interaction (Lakowicz, 1999; Valeur) and, along with its characteristics of being inexpensive and easy to implement, it becomes a very attractive method to be used on sensors construction.

Therefore, materials for biosensors can be chosen based on the nature of the target, the interaction that might occur between it and a specific class of fluorophore and a photophysical process that leads to an easy-of-measure optical effect. Thus, biosensors can concentrate on evaluating the effect of interaction on steady-state fluorescence intensity, fluorescence lifetime, spectral shifts, fluorescence anisotropy and mechanisms of radioactive energy transfer such as FRET (Fluorescence Resonance Energy Transfer). (Lakowicz, 1999) So forth, many features of fluorescent responses can be used to identify and quantitatively determine species into any environment. Even indirect optical effects are important, as in the case of the $\mathrm{Zn}$ (II) sensor developed by Godwin et al (Godwin e Berg, 1996), in which the FRET process informs about the quantity of $\mathrm{Zn}$ (II) in cells at the moment this metal binds to Zinc finger peptides. Since zinc finger peptides tightly and selectively bind zinc, with a $K_{d}$ of $5.7(+1.3) \times 10^{-12} \mathrm{~mol} \mathrm{~L}^{-1}$ at $\mathrm{pH} 7.0$ (Krizek, Merkle et al., 1993), they provide an ideal proposal for a selective zinc probe. These studies showed that the activity of this fluorophore is based on changes in fluorescence energy transfer due to the metal-induced changing in conformation of this peptide.

Another approach is sensing based on fluorescence quenching. The biosensor proposed by Sharma et al. (Sharma e Gohil, 2010) is based on the evaluation of fluorescence quenching upon intermolecular interactions between a fluorescent marker and ferric ions present in the azotobactin secreted by the nitrogen-fixing bacteria Azotobacter vinelandii. The resulting fluorescence quenching is dependent on the high affinity of the fluorophore by Fe(III) ions and can be used to quantitatively determine Fe(III) in several biological media, including human serum.

Several peptides present the ability of self-assembly to form nanostructures that have found a number of interesting applications. Among them is their use as support matrix for the construction of biosensors. A common way to prepare them is to employ a fluorescent compound such as quantum dots and enzymes as receptors physically adhered to these nanostructures, as those developed by Cao et al., (Cao, Ye et al., 2008) or using free enzymes and colloidal quantum dots dissolved in an aqueous solution as those developed by CostaFernandez et al (Costa-Fernandez, Pereiro et al., 2006).

Some had aimed at the development of supports that can efficiently incorporate bioreceptors and fluorescent interacting compounds, which is the critical step for the development of biosensors and bioelectronic devices. Fabrication of enzyme-based sensors, for example, involves the incorporation of bioreceptors and quantum dots within a gel matrix. In the peptide hydrogel-based biosensor developed by Kim et al, (Kim, Lim et al., 2011), which consists of a biosensing platform using encapsulation of enzyme bioreceptors and quantum dots as fluorescent markers, enzymes and quantum dots were physically immobilized within the peptide hydrogel and the resulting matrix presented some practical advantages such as simplicity of fabrication, based on the peptide property of self-assembly, very efficient diffusion of target analytes through the hydrogel and efficient encapsulation of fluorescent markers and bioreceptors. A scheme of the trapping of quantum dots into the self-assembled hydrogel as proposed by Kim et al. is shown in Fig. 12. The aim of this work was to provide an advanced sensor format and, perhaps, a protective carrier for bioreceptors. Based also on the self-assembly ability of peptides, Martins et al (Martins et al., 
2011 in press)showed that fluorophores such as pyrene derivatives can be sorbed onto nanostructured peptides with no effect on nanostructure formation process and depending on preparative environment, such as, preparation on distinct $\mathrm{pH}$ ranges, these fluorophores can be sorbed on the surface of nanostructures or intercalate to the $\pi$-stacked nanostructure, which are properties that can be exploited aiming at the delivery of components and sensor construction. This work also demonstrated that pyrene fluorescent response is dependent on the interaction with the environment in which nanostructures are found. Another approach that has been used by a number of authors (Sackmann, 1996; Kung, Kam et al., 2000; Merzlyakov, Li et al., 2006) is the development of supporting matrices based on bilayer lipid membranes in which the sensing property is based on monitoring changes in the electrical properties of the bilayer (Terrettaz, Ulrich et al., 2001; Worsfold, Toma et al., 2004). These methods present the important advantage of enabling the monitoring of single ion channel events, as shown by Cheng et al. (Cheng, Bushby et al., 2001). Nevertheless, not much is known about the stability of these systems and this is a matter of concern, since earlier studies (Song e Swanson, 1999) showed that bilayers applied as matrices for optical sensors are unstable when directly attached to glass substrates for optical waveguide applications (Kelly, Grace et al., 1999; Song, Shi et al., 2000). A way to reduce the damaging effects of the substrate on the stability of the lipid bilayer is to use layers based on a protein linker that act as spacer layers between the substrate and the resultant bilayer, as proposed by Worsfold et al.

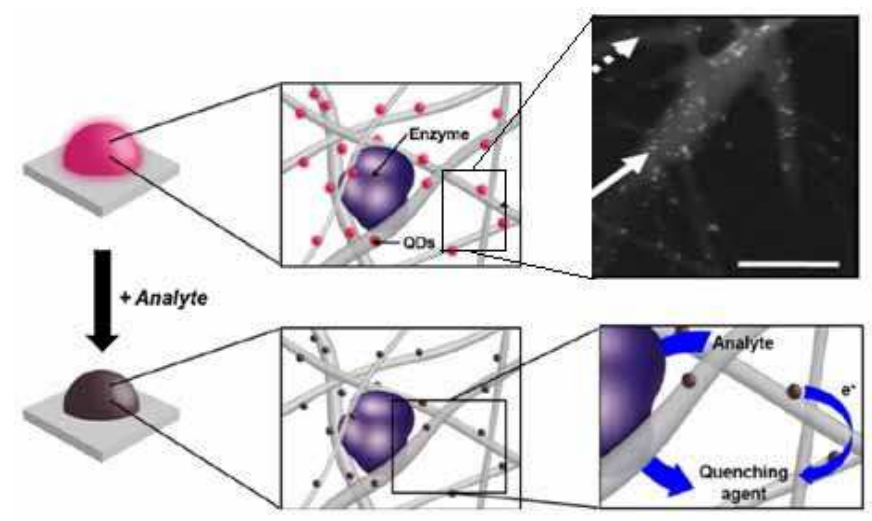

Fig. 12. Scheme of the development of a photoluminescent peptide hydrogel through the self-assembly of FmocFF building blocks and their PL quenching associated with the enzymatic detection of analytes, as shown by Kim et al. In this figure, the high photoluminescent efficiency of quantum dots on the peptide hydrogel is shown. Upon addition of analytes, a quenching agent (i.e., electron acceptor) is produced by an enzyme catalyzed reaction, which results in a decrease of luminescence of the peptide hydrogel, caused by the action of the quenching agent that absorbs the electrons of the quantum dots that were excited. The HAADF STEM image shows the nanostructure of the FmocFF hydrogel containing quantum dots. Solid and dotted arrows indicate the CdTe quantum dots and peptide nanofibers, respectively. Figure adapted from Kim et al. Reprinted with permission from Kim, J. H., S. Y. Lim, et al. (2011). "Self-assembled, photoluminescent peptide hydrogel as a versatile platform for enzyme-based optical biosensors." Biosensors and Bioelectronics 26(5): 1860-1865. (C) 2010 Elsevier B.V. 
Fluorescence anisotropy can be used as a sensing technique due to its capability of providing a response to target binding by recording the change of rotational mobility of the fluorescent marker. Anisotropy is based on the fact that the free fluorescent sensor molecule rotates rapidly and displays a low value of anisotropy. When attached to a target, a complex of a bigger size of rotating unit is formed, leading to an anisotropy increase. This principle is employed, for example, in homogeneous fluorescence polarization immunoassay for detection of antigens or antibodies (Nielsen, Lin et al., 2000), where either the antigen or the antibody can be detected in solution with the labeled fluorescent probe. The fluorescence anisotropy increases due to an increase in the size of the complex formed between the analyte and the fluorophore. Using this same principle, fluorescence polarization can also inform about the affinity of the antigen-antibody interaction (Smallshaw, Brokx et al., 1998). Fluorescence lifetime decay is also a property that can be useful in sensing activities. Based on the concept that fluorescence lifetime is representative of the interaction between a fluorophore and the environment that contains it, (Lakowicz, 1999) sensing is achieved when the difference in fluorescence lifetimes between a target-free and a target-bound forms of a sensor can be detected. The sensor constructed by Khan et al. (Khan, Saxl et al., 2010) is an example. It works based on the synthesis of mutants of a glucose/galactose-binding protein (GBP), labeled with the fluorophore Badan, in order to produce a fluorescence-based glucose sensing system with an operating range compatible with continuous glucose monitoring in patients with diabetes mellitus. Results presented showed that the triple mutant H152C/A213R/L238S-Badan gave total enhance on fluorescence intensity of nearly $200 \%$ on the addition of glucose, with a binding constant, $\mathrm{K}_{\mathrm{d}}=11 \mathrm{mM}$, and operating range of 1 to $100 \mathrm{mM}$, with similar responses in both buffer and serum. An enhancement on fluorescence lifetime of this mutant of $70 \%$ was also reported and the GBP mutant H152C/A213R/L238S, when labeled with Badan, showed to be suitable as a sensor of glucose monitoring in diabetes.

Another example is the sensor developed by Massey and Krull (Massey e Krull, 2010) in which the fluorescent properties of a thiazole derivative was studied for the development of a structure with application at solid-phase analyses, when immobilized. The structure, prepared by self-assembly, is capable of detection of nucleic acid hybridization. The proposal uses Neutravidin as a templating platform and combines a biotinylated probe oligonucleotide with thiazole orange as a physically immobilized intercalating dye. It works based on the assumption that intercalating fluorophores exhibits different binding affinities to single-stranded DNA (ssDNA) and double-stranded DNA (dsDNA), which provides fluorescence intensity and lifetime changes in different environments that are able to distinguish between intercalation and other binding events. In special, thiazole orange is capable of undergoing significant fluorescence enhancement upon intercalation into dsDNA. This work presented some noteworthy results. Solution-phase fluorescence lifetime data showed a biexponential behavior for sensors, suggesting intercalation as well as a significant secondary binding mode for the immobilized thiazole orange. They also found that the secondary binding mechanism for the fluorophore to DNA could be decreased, and the fluorophore could be shifted to intercalative binding modes, by simply adjusting the solution conditions, namely, by adjusting environment ionic force. This leads to a remarkable fivefold fluorescence intensity increase.

Collisional dynamic quenching produces a substantial change in lifetime. In this way, best results in lifetime sensing are obtained when determining targets that contain strong 
collisional quenchers of fluorescence, such as oxygen, sulfur dioxide or nitrogen oxide (Szmacinski H, 1994). Again, the disadvantage of this method is the difficulty in choosing the ideal fluorophore, since binding characteristics and optical response can vary tremendously from one molecular structure to another.

Another approach of fluorescence-based sensing is to take advantage of several fluorescence effects that occur when two dyes are put together. In this sense, the formation of a complex of two molecules, in which one of them is in its excited state, named excimer, is the property exploited in sensor construction. Its function is based on the fact that in one of the sensor states, when with bound or unbound target molecules, the two fluorophore molecules are close to each other but distant enough to form an excimer upon excitation, while in the other state they move apart and excimers are not observed. This was the idea of Yang et al. in the construction of sensors for cations (Yang, Lin et al., 2001; Liao, Chen et al., 2002) when constructing a sensor for anions. Furthermore, since pyrene is a fluorophore that can easily form excimers, it has been used for the construction of sensors for DNA detection, as described by Mahara et al. (Mahara, Iwase et al., 2002) as it needs the formation of pyreneconjugated oligonucleotides where excimers can occur or in sensor for protein-protein recognition, as described by Sahoo et al. (Sahoo, Narayanaswami et al., 2000) Martins et al. (Martins et al., 2011 in press) showed that peptide nanostructures containing pyrene derivatives sorbed onto them can sense distinct environments, with effect on fluorescence lifetimes, even when excimer are not formed.

According to several authors, the challenge of developing these types of sensors is in the proposal of an all-serving-sensor. This has been very important because the number of systems that can be used for constructing fluorescence sensors is enormous and the focus of new research has been on enhancing fluorescence response of sensors for specific uses, in order to provide even more sensitive sensors than the search for materials to construct a single sensor that could be used in a large variety of systems.

\subsection{Piezoelectric biosensors}

Piezoelectricity is the crystal property to generate voltage in response to external vibration. This effect is reversible and, thus, all piezoelectric crystals vibrate in the presence of an electric field. The frequency (f) of this vibration depends on the thickness of the crystal, although it constitutes a characteristic of each crystal. This characteristic frequency changes when the crystal molecules are adsorb onto a surface. The relation between the mass transport on the surface of the piezoelectric crystal and the transduced signal is given by:

$$
\Delta f=\frac{K_{p} f^{2} \Delta m}{A}
$$

where, $\Delta \mathrm{f}$ is the characteristic frequency variation, $\Delta m$ is the mass change of the adsorbed material, $\mathrm{K}_{\mathrm{p}}$ is a constant of the crystal and $\mathrm{A}$ is the surface area adsorbed.

As the frequency variation is proportional to the mass variation of the adsorbed material, such variation can be determined by impedance. Therefore, these biosensors contains enzymes immobilized on the piezoelectric crystals that act as transducers of the electrical signal produced at the interface. An example is a transducer to detect formaldehyde, which is formed by dehydrogenase immobilized on a quartz crystal (Kumar, 2000). 
The main drawbacks of piezoelectric biosensors are the interference of atmospheric moisture on measure and the fact that they cannot be used to determine analytes in solution (Guilbault, 1991). However, piezoelectric biosensors are relatively cheap, small and produce fast responses. (Barnes, Dsilva et al., 1991)

The piezoelectric materials most today are inorganic, such as $\mathrm{PB}(\mathrm{Zr}, \mathrm{Ti}) \mathrm{O}_{3}$. (Kobayashi, Okada et al., 2010). However, these materials can only be obtained at high temperatures $\left(\sim 600{ }^{\circ} \mathrm{C}\right)$, are sensitive to defects and are not biocompatible. The evidenced piezoelectric effect in nanotubes made them useful in biological systems. Kholkin and co-workers reported that the ${ }^{+} \mathrm{NH}_{3}$-Phe-Phe-COO- nanotube nanotube belongs to the $\mathrm{P}_{1}$ asymmetric group, which confer it the piezoelectricity (Kholkin, Amdursky et al., 2010). AFM images were performed while a voltage $V_{a c}$ was applied. Under these conditions, variation of the shear component of the tensor $\left(\mathrm{d}_{15}\right)$ was observed, suggesting a component of polarization along the axis of nanotube (Kobayashi, Okada et al., 2010). These results corroborate with peptide nanotubes profiles obtained by electrostatic force microscopy (Clausen, Jensen et al., 2008).

Direct quantification of the piezoelectric effect in peptide nanotubes proves tricky due to tubular geometry. However, indirect calculations showed that the coefficient $d_{15}$ in peptide nanotubes. with $\sim 100 \mathrm{~nm}$ diameter is twice lower than that observed for the bulk of $\mathrm{LiNbO}_{3}$, (Smith e Welsh, 1971), ie $d_{15} \approx 35$ pm.V-1 (Kobayashi, Okada et al., 2010). The intense piezoelectric effect observed in peptide nanotubes makes these materials promising candidates for generating "green nanopiezoelectricity", allowing the construction of biosensors that operate in direct contact with living tissues.

\subsection{Implantable nanostructured biosensors}

Implantable biosensors are of great impact in nanobiomedicine. However the achievement of ideal devices is not trivial and depends on factors such as biocompatibility, long-term stability, selectivity, reproducibility and miniaturization (Sadik, Aluoch et al., 2009). Nanobiosensors must exhibit dimensions of elementary biomolecules ( $1000 \mathrm{~nm})$ such as enzymes, proteins and DNA, and are promising in the monitoring of various physical and biochemical parameters such as body temperature, oxygen and blood glucose leves (Hiller, Kranz et al., 1996; Fiorito e De Torresi, 2001; Kros, Van Hovell et al., 2001) (Choi, Han et al., 2007). Among the applications, implantable biosensors are applied on DNA testing and pregnancy monitoring (Erdem, Karadeniz et al., 2009). Implantable biosensors with continuous fluorescence for application in remote sensing of individuals (Ellis-Behnke, Liang et al., 2006) have also been investigated.

Among the various materials used in the fabrication of implantable biosensors, the biocompatibility in devices based on bio-functionalized CNTs has attracted the attention of some scientists ( $\mathrm{Li}$, Chen et al., 2006), nevertheless, the use of CNTs as implantable biosensors is questionable, since the isolated CNTs tend to cluster, increasing its cytotoxicity. (Cui, Tian et al., 2005) The functionalization of carbon nanotubes with peptides has been investigated to increase its biocompatibility and solubility (Pantarotto, Partidos et al., 2003; Li, Chen et al., 2006). Biocompatibility of biosensors is achieved by enabling interactions between the device and the biological system.

Fabrication of implantable biosensors is subjected to several factors such as bioadaptability (biological adaptation of the physiological environment to implanted material), biostability 
(absence of host immune reaction after implantation), interfacial biocompatibility (release of substance), physical analysis and morphological and mechanical properties. The biocompatibility is attributed according to the response type and the region in which the device is implanted. Thus, the biosensors are classified as bioinerts if no implant-tissue interaction; biodegradable if gradual degradation occurs on biological action, bioabsorbable, if incorporation of the implant by host tissue occurs and bioactive, if formation of new tissue at the implant-tissue interfaces occurs.

The advantages of biosensors based on peptide nanotubes are solubility in water and they can be functionalized depending on the application of interest.

\section{Acknowledgment}

UFABC, FAPESP, CNPq, Capes, INCT in Bioanalytics.

\section{References}

Adler-Abramovich, L., D. Aronov, et al. Self-assembled arrays of peptide nanotubes by vapour deposition. Nature Nanotechnology, v.4, n.12, Dec, p.849-854. 2009.

Adler-Abramovich, L., M. Badihi-Mossberg, et al. Characterization of PeptideNanostructure-Modified Electrodes and Their Application for Ultrasensitive Environmental Monitoring. Small, v.6, n.7, Apr 9, p.825-831. 2010.

Adler-Abramovich, L., M. Reches, et al. Thermal and chemical stability of diphenylalanine peptide nanotubes: Implications for nanotechnological applications. Langmuir, v.22, n.3, Jan 31, p.1313-1320. 2006.

Aizenberg, J. \& P. Fratzl. Biological and Biomimetic Materials. Advanced Materials, v.21, n.4, Jan 26, p.387-388. 2009.

Altschuh, D., S. Oncul, et al. Fluorescence sensing of intermolecular interactions and development of direct molecular biosensors. Journal of Molecular Recognition, v.19, n.6, Nov-Dec, p.459-477. 2006.

Banerjee, I. A., G. Muniz, et al. Mineralization of semiconductor nanocrystals on peptidecoated bionanotubes and their $\mathrm{pH}$-dependent morphology changes. Journal of Nanoscience and Nanotechnology, v.7, n.7, Jul, p.2287-2292. 2007.

Banerjee, I. A., L. T. Yu, et al. Thiolated peptide nanotube assembly as arrays on patterned Au substrates. Nano Letters, v.4, n.12, Dec, p.2437-2440. 2004.

Barnes, C., C. Dsilva, et al. A Concanavalin a-Coated Piezoelectric Crystal Biosensor. Sensors and Actuators B-Chemical, v.3, n.4, Apr, p.295-304. 1991.

Birks, J. B. Photophysics of Aromatic Molecules (Wiley monographs in chemical physics): John Wiley \& Sons Ltd 1970 (Wiley Interscience)

Brea, R. J., L. Castedo, et al. Large-diameter self-assembled dimers of alpha,gamma-cyclic peptides, with the nanotubular solid-state structure of cyclo-[(L-Leu-D-N-Megamma-Acp)(4-)] 4CHCl(2)COOH. Chemical Communications, n.31, p.3267-3269. 2007.

Cao, L. H., J. Ye, et al. A New Route to the Considerable Enhancement of Glucose Oxidase (GOx) Activity: The Simple Assembly of a Complex from CdTe Quantum Dots and 
GOx, and Its Glucose Sensing. Chemistry-a European Journal, v.14, n.31, p.96339640. 2008.

Cheng, J., J. C. Zhu, et al. Molecular modeling investigation of adsorption of self-assembled peptide nanotube of cyclo-[(1R,3S)-gamma-Acc-D-Phe](3) in $\mathrm{CHCl}$. Chemical Physics, v.333, n.2-3, Mar 30, p.105-111. 2007.

Cheng, Y. L., R. J. Bushby, et al. Single ion channel sensitivity in suspended bilayers on micromachined supports. Langmuir, v.17, n.4, Feb 20, p.1240-1242. 2001.

Cho, E. C., J. W. Choi, et al. Fabrication of an electrochemical immunosensor with selfassembled peptide nanotubes. Colloids and Surfaces a-Physicochemical and Engineering Aspects, v.313, Feb 1, p.95-99 704. 2008.

Choi, H. N., J. H. Han, et al. Amperometric glucose biosensor based on glucose oxidase encapsulated in carbon nanotube-titania-nafion composite film on platinized glassy carbon electrode. Electroanalysis, v.19, n.17, Sep, p.1757-1763. 2007.

Cipriano, T. C., P. M. Takahashi, et al. Spatial organization of peptide nanotubes for electrochemical devices. Journal of Materials Science, v.45, n.18, Sep, p.5101-5108. 2010.

Clark, L. C., R. Wolf, et al. Continuous Recording of Blood Oxygen Tensions by Polarography. Journal of Applied Physiology, v.6, n.3, p.189-193. 1953.

Clausen, C. H., J. Jensen, et al. Qualitative Mapping of Structurally Different Dipeptide Nanotubes. Nano Letters, v.8, n.11, Nov, p.4066-4069. 2008.

Colombo, G., P. Soto, et al. Peptide self-assembly at the nanoscale: a challenging target for computational and experimental biotechnology. Trends in Biotechnology, v.25, n.5, May, p.211-218. 2007.

Costa-Fernandez, J. M., R. Pereiro, et al. The use of luminescent quantum dots for optical sensing. Trac-Trends in Analytical Chemistry, v.25, n.3, Mar, p.207-218. 2006.

Cui, D. X., F. R. Tian, et al. Effect of single wall carbon nanotubes on human HEK293 cells. Toxicology Letters, v.155, n.1, Jan 15, p.73-85. 2005.

De La Rica, R. \& H. Matsui. Applications of peptide and protein-based materials in bionanotechnology. Chemical Society Reviews, v.39, n.9, p.3499-3509. 2010.

De La Rica, R., E. Mendoza, et al. Label-Free Pathogen Detection with Sensor Chips Assembled from Peptide Nanotubes. Angewandte Chemie-International Edition, v.47, n.50, p.9752-9755. 2008.

De Lorimier, R. M., J. J. Smith, et al. Construction of a fluorescent biosensor family. Protein Science, v.11, n.11, Nov, p.2655-2675. 2002.

De Santis, P., S. Morosetti, et al. Peptides with regular enantiomeric sequences: A wide class of modular self-assembling architectures. Journal of Nanoscience and Nanotechnology, v.7, n.7, Jul, p.2230-2238. 2007.

Demirel, G., N. Malvadkar, et al. Control of Protein Adsorption onto Core-Shell Tubular and Vesicular Structures of Diphenylalanine/Parylene. Langmuir, v.26, n.3, Feb 2, p.1460-1463. 2010.

Ellis-Behnke, R. G., Y. X. Liang, et al. Nano neuro knitting: Peptide nanofiber scaffold for brain repair and axon regeneration with functional return of vision. Proceedings of the National Academy of Sciences of the United States of America, v.103, n.13, Mar 28, p.5054-5059. 2006. 
Erdem, A., H. Karadeniz, et al. Single-Walled Carbon Nanotubes Modified Graphite Electrodes for Electrochemical Monitoring of Nucleic Acids and Biomolecular Interactions. Electroanalysis, v.21, n.3-5, Feb, p.464-471. 2009.

Fiorito, P. A. \& S. I. C. De Torresi. Glucose amperometric biosensor based on the coimmobilization of glucose oxidase (GOx) and ferrocene in poly(pyrrole) generated from ethanol/water mixtures. Journal of the Brazilian Chemical Society, v.12, n.6, Nov-Dec, p.729-733. 2001.

Ghadiri, M. R., J. R. Granja, et al. Self-Assembling Organic Nanotubes Based on a Cyclic Peptide Architecture. Nature, v.366, n.6453, Nov 25, p.324-327. 1993.

Godwin, H. A. \& J. M. Berg. A fluorescent zinc probe based on metal-induced peptide folding. Journal of the American Chemical Society, v.118, n.27, Jul 10, p.6514-6515. 1996.

Guha, S. \& A. Banerjee. Self-Assembled Robust Dipeptide Nanotubes and Fabrication of Dipeptide-Capped Gold Nanoparticles on the Surface of these Nanotubes. Advanced Functional Materials, v.19, n.12, Jun 23, p.1949-1961. 2009.

Guilbault, G. G. Biosensors. Current Opinion in Biotechnology, v.2, n.1, Feb, p.3-8. 1991.

Hartgerink, J. D., J. R. Granja, et al. Self-assembling peptide nanotubes. Journal of the American Chemical Society, v.118, n.1, Jan 10, p.43-50. 1996.

Hauser, C. A. E. \& S. G. Zhang. Designer self-assembling peptide nanofiber biological materials. Chemical Society Reviews, v.39, n.8, p.2780-2790. 2010.

He, Q., L. Duan, et al. Microcapsules containing a biomolecular motor for ATP biosynthesis. Advanced Materials, v.20, n.15, Aug 4, p.2933-2937. 2008.

Hiller, M., C. Kranz, et al. Amperometric biosensors produced by immobilization of redox enzymes at polythiophene-modified electrode surfaces. Advanced Materials, v.8, n.3, Mar, p.219-\&. 1996.

Hirata, T., F. Fujimura, et al. A novel polypseudorotaxane composed of cyclic beta-peptide as bead component. Chemical Communications, n.10, p.1023-1025. 2007.

Kelly, D., K. M. Grace, et al. Integrated optical biosensor for detection of multivalent proteins. Optics Letters, v.24, n.23, Dec 1, p.1723-1725. 1999.

Khan, F., T. E. Saxl, et al. Fluorescence intensity- and lifetime-based glucose sensing using an engineered high-K-d mutant of glucose/galactose-binding protein. Analytical Biochemistry, v.399, n.1, Apr 1, p.39-43. 2010.

Kholkin, A., N. Amdursky, et al. Strong Piezoelectricity in Bioinspired Peptide Nanotubes. Acs Nano, v.4, n.2, Feb, p.610-614. 2010.

Kim, J., T. H. Han, et al. Role of Water in Directing Diphenylalanine Assembly into Nanotubes and Nanowires. Advanced Materials, v.22, n.5, Feb 2, p.583-+. 2010.

Kim, J. H., S. Y. Lim, et al. Self-assembled, photoluminescent peptide hydrogel as a versatile platform for enzyme-based optical biosensors. Biosensors and Bioelectronics, v.26, n.5, p.1860-1865. 2011.

Kobayashi, T., H. Okada, et al. A digital output piezoelectric accelerometer using a $\mathrm{Pb}(\mathrm{Zr}$, Ti)O-3 thin film array electrically connected in series. Smart Materials \& Structures, v.19, n.10, Oct, p.-. 2010.

Krizek, B. A., D. L. Merkle, et al. Ligand Variation and Metal-Ion Binding-Specificity in Zinc Finger Peptides. Inorganic Chemistry, v.32, n.6, Mar 17, p.937-940. 1993. 
Kros, A., W. F. M. Van Hovell, et al. Poly(3,4-ethylenedioxythiophene)-based glucose biosensors. Advanced Materials, v.13, n.20, Oct 16, p.1555-+. 2001.

Kumar, A. Biosensors Based on Piezoelectric Crystal Detectors: Theory and Application. JOM-e. 522000.

Kung, L. A., L. Kam, et al. Patterning hybrid surfaces of proteins and supported lipid bilayers. Langmuir, v.16, n.17, Aug 22, p.6773-6776. 2000.

Lakowicz, J. R. Principles of Fluorescence Spectroscopy: Springer. 1999. 725 pages p.

Li, X. J., W. Chen, et al. Direct measurements of interactions between polypeptides and carbon nanotubes. Journal of Physical Chemistry B, v.110, n.25, Jun 29, p.1262112625. 2006.

Liao, J. H., C. T. Chen, et al. A novel phosphate chemosensor utilizing anion-induced fluorescence change. Organic Letters, v.4, n.4, Feb 21, p.561-564. 2002.

Lu, K., J. Jacob, et al. Exploiting amyloid fibril lamination for nanotube self-assembly. Journal of the American Chemical Society, v.125, n.21, May 28, p.6391-6393. 2003.

Mahara, A., R. Iwase, et al. Bispyrene-conjugated 2 '-O-methyloligonucleotide as a highly specific RNA-recognition probe. Angewandte Chemie-International Edition, v.41, n.19, p.3648-3650. 2002.

Marvin, J. S., E. E. Corcoran, et al. The rational design of allosteric interactions in a monomeric protein and its applications to the construction of biosensors. Proceedings of the National Academy of Sciences of the United States of America, v.94, n.9, Apr 29, p.4366-4371. 1997.

Massey, M. e U. J. Krull. Towards a fluorescent molecular switch for nucleic acid biosensing. Analytical and Bioanalytical Chemistry, v.398, n.4, Oct, p.1605-1614. 2010.

Mcfarland, S. A. \& N. S. Finney. Fluorescent chemosensors based on conformational restriction of a biaryl fluorophore. Journal of the American Chemical Society, v.123, n.6, Feb 14, p.1260-1261. 2001.

Merzlyakov, M., E. Li, et al. Directed assembly of surface-supported bilayers with transmembrane helices. Langmuir, v.22, n.3, Jan 31, p.1247-1253. 2006.

Motesharei, K. e M. R. Ghadiri. Diffusion-limited size-selective ion sensing based on SAMsupported peptide nanotubes. Journal of the American Chemical Society, v.119, n.46, Nov 19, p.11306-11312. 1997.

Nielsen, K., M. Lin, et al. Fluorescence polarization immunoassay: Detection of antibody to Brucella abortus. Methods-a Companion to Methods in Enzymology, v.22, n.1, Sep, p.71-76. 2000.

Pantarotto, D., C. D. Partidos, et al. Synthesis, structural characterization, and immunological properties of carbon nanotubes functionalized with peptides. Journal of the American Chemical Society, v.125, n.20, May 21, p.6160-6164. 2003.

Poteau, R. \& G. Trinquier. All-cis cyclic peptides. Journal of the American Chemical Society, v.127, n.40, Oct 12, p.13875-13889. 2005.

Reches, M. \& E. Gazit. Casting metal nanowires within discrete self-assembled peptide nanotubes. Science, v.300, n.5619, Apr 25, p.625-627. 2003. 
Formation of closed-cage nanostructures by self-assembly of aromatic dipeptides. Nano Letters, v.4, n.4, Apr, p.581-585. 2004.

Controlled patterning of aligned self-assembled peptide nanotubes. Nature Nanotechnology, v.1, n.3, Dec, p.195-200. 2006.

Ryu, J. \& C. B. Park. High-Temperature Self-Assembly of Peptides into Vertically WellAligned Nanowires by Aniline Vapor. Advanced Materials, v.20, n.19, Oct 2, p.3754-+. 2008a.

Solid-phase growth of nanostructures from amorphous peptide thin film: Effect of water activity and temperature. Chemistry of Materials, v.20, n.13, Jul 8, p.4284-4290. 2008b.

Synthesis of Diphenylalanine/Polyaniline Core/Shell Conducting Nanowires by Peptide Self-Assembly. Angewandte Chemie-International Edition, v.48, n.26, p.4820-4823. 2009.

High Stability of Self-Assembled Peptide Nanowires Against Thermal, Chemical, and Proteolytic Attacks. Biotechnology and Bioengineering, v.105, n.2, Feb 1, p.221-230. 2010.

Sackmann, E. Supported membranes: Scientific and practical applications. Science, v.271, n.5245, Jan 5, p.43-48. 1996.

Sadik, O. A., A. O. Aluoch, et al. Status of biomolecular recognition using electrochemical techniques. Biosensors \& Bioelectronics, v.24, n.9, May 15, p.2749-2765. 2009.

Sahoo, D., V. Narayanaswami, et al. Pyrene excimer fluorescence: A spatially sensitive probe to monitor lipid-induced helical rearrangement of apolipophorin III. Biochemistry, v.39, n.22, Jun 6, p.6594-6601. 2000.

Sanchez, C., H. Arribart, et al. Biomimetism and bioinspiration as tools for the design of innovative materials and systems. Nature Materials, v.4, n.4, Apr, p.277-288. 2005.

Sharma, M. \& N. K. Gohil. Optical features of the fluorophore azotobactin: Applications for iron sensing in biological fluids. Engineering in Life Sciences, v.10, n.4, Aug, p.304310. 2010.

Shklovsky, J., P. Beker, et al. Bioinspired peptide nanotubes: Deposition technology and physical properties. Materials Science and Engineering B-Advanced Functional Solid-State Materials, v.169, n.1-3, May 25, p.62-66. 2010.

Sima, V., C. Cristea, et al. Electroanalytical properties of a novel biosensor modified with zirconium alcoxide porous gels for the detection of acetaminophen. Journal of Pharmaceutical and Biomedical Analysis, v.48, n.4, Dec 1, p.11951200. 2008.

Singh, G., A. M. Bittner, et al. Electrospinning of diphenylalanine nanotubes. Advanced Materials, v.20, n.12, Jun 18, p.2332-+. 2008.

Smallshaw, J. E., S. Brokx, et al. Determination of the binding constants for three HPrspecific monoclonal antibodies and their fab fragments. Journal of Molecular Biology, v.280, n.5, Jul 31, p.765-774. 1998.

Smith, R. T. \& F. S. Welsh. Temperature Dependence of Elastic, Piezoelectric, and Dielectric Constants of Lithium Tantalate and Lithium Niobate. Journal of Applied Physics, v.42, n.6, p.2219-\&. 1971. 
Song, J., Q. Cheng, et al. "Smart" materials for biosensing devices: Cell-mimicking supramolecular assemblies and colorimetric detection of pathogenic agents. Biomedical Microdevices, v.4, n.3, Jul, p.213-221. 2002.

Song, X. D., J. Shi, et al. Flow cytometry-based biosensor for detection of multivalent proteins. Analytical Biochemistry, v.284, n.1, Aug 15, p.35-41. 2000.

Song, X. D. \& B. I. Swanson. Direct, ultrasensitive, and selective optical detection of protein toxins using multivalent interactions. Analytical Chemistry, v.71, n.11, Jun 1, p.2097-2107. 1999.

Song, Y. J., S. R. Challa, et al. Synthesis of peptide-nanotube platinum-nanoparticle composites. Chemical Communications, n.9, May 7, p.1044-1045. 2004.

Szmacinski H, L. J. Lifetime-based sensing. New York: Plenum Press, v.4. 1994 (InTopics in fluorescence spectroscopy (Vol. 4))

Terrettaz, S., W. P. Ulrich, et al. Immunosensing by a synthetic ligand-gated ion channel. Angewandte Chemie-International Edition, v.40, n.9, p.1740-1743. 2001.

Thevenot, D. R., K. Toth, et al. Electrochemical biosensors: Recommended definitions and classification - (Technical Report). Pure and Applied Chemistry, v.71, n.12, Dec, p.2333-2348. 1999.

Valeur, B. Molecular Fluorescence: Principles and Applications. New York: Wiley-VCH. 2001

Wang, J. Electrochemical glucose biosensors. Chemical Reviews, v.108, n.2, Feb, p.814-825. 2008.

Wang, J. \& Y. H. Lin. Functionalized carbon nanotubes and nanofibers for biosensing applications. Trac-Trends in Analytical Chemistry, v.27, n.7, Jul-Aug, p.619-626. 2008.

Wang, J., D. L. Wang, et al. Photoluminescence of water-soluble conjugated polymers: Origin of enhanced quenching by charge transfer. Macromolecules, v.33, n.14, Jul 11, p.5153-5158. 2000.

Worsfold, O., C. Toma, et al. Development of a novel optical bionanosensor. Biosensors \& Bioelectronics, v.19, n.11, Jun 15, p.1505-1511. 2004.

Yan, X. H., Y. Cui, et al. Organogels based on self-assembly of diphenylalanine peptide and their application to immobilize quantum dots. Chemistry of Materials, v.20, n.4, Feb 26, p.1522-1526. 2008.

Yang, H., S. Y. Fung, et al. Ionic-Complementary Peptide Matrix for Enzyme Immobilization and Biomolecular Sensing. Langmuir, v.25, n.14, Jul 21, p.7773-7777. 2009.

Yang, J. S., C. S. Lin, et al. Cu2+-induced blue shift of the pyrene excimer emission: A new signal transduction mode of pyrene probes. Organic Letters, v.3, n.6, Mar 22, p.889892. 2001.

Yanlian, Y., K. Ulung, et al. Designer self-assembling peptide nanomaterials. Nano Today, v.4, n.2, p.193-210. 2009.

Yeh, J. I., A. Lazareck, et al. Peptide nanowires for coordination and signal transduction of peroxidase biosensors to carbon nanotube electrode arrays. Biosensors \& Bioelectronics, v.23, n.4, Nov 30, p.568-574. 2007.

Yemini, M., M. Reches, et al. Peptide nanotube-modified electrodes for enzyme-biosensor applications. Analytical Chemistry, v.77, n.16, Aug 15, p.5155-5159. 2005. Novel 
electrochemical biosensing platform using self-assembled peptide nanotubes. Nano Letters, v.5, n.1, Jan, p.183-186. 2005.

Yoo, E. H. e S. Y. Lee. Glucose Biosensors: An Overview of Use in Clinical Practice. Sensors, v.10, n.5, May, p.4558-4576. 2010. 


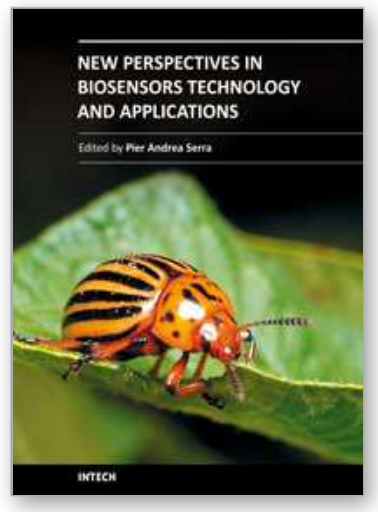

\author{
New Perspectives in Biosensors Technology and Applications \\ Edited by Prof. Pier Andrea Serra
}

ISBN 978-953-307-448-1

Hard cover, 448 pages

Publisher InTech

Published online 27, July, 2011

Published in print edition July, 2011

\begin{abstract}
A biosensor is a detecting device that combines a transducer with a biologically sensitive and selective component. Biosensors can measure compounds present in the environment, chemical processes, food and human body at low cost if compared with traditional analytical techniques. This book covers a wide range of aspects and issues related to biosensor technology, bringing together researchers from 12 different countries. The book consists of 20 chapters written by 69 authors and divided in three sections: Biosensors Technology and Materials, Biosensors for Health and Biosensors for Environment and Biosecurity.
\end{abstract}

\title{
How to reference
}

In order to correctly reference this scholarly work, feel free to copy and paste the following:

Wendel Alves, Wellington Alves, Camila Pinheiro Sousa, Sergio Kogikoski Jr., Rondes Ferreira Da Silva, Heliane Amaral, Michelle Silva Liberato, Vani Xavier De Oliveira Jr., Tatiana Martins and Pedro Mitsuo Takahashi (2011). Biosensors Based on Biological Nanostructures, New Perspectives in Biosensors Technology and Applications, Prof. Pier Andrea Serra (Ed.), ISBN: 978-953-307-448-1, InTech, Available from: http://www.intechopen.com/books/new-perspectives-in-biosensors-technology-and-applications/biosensorsbased-on-biological-nanostructures

\section{INTECH}

open science | open minds

\section{InTech Europe}

University Campus STeP Ri

Slavka Krautzeka 83/A

51000 Rijeka, Croatia

Phone: +385 (51) 770447

Fax: +385 (51) 686166

www.intechopen.com

\section{InTech China}

Unit 405, Office Block, Hotel Equatorial Shanghai

No.65, Yan An Road (West), Shanghai, 200040, China

中国上海市延安西路65号上海国际贵都大饭店办公楼 405 单元

Phone: +86-21-62489820

Fax: +86-21-62489821 
(C) 2011 The Author(s). Licensee IntechOpen. This chapter is distributed under the terms of the Creative Commons Attribution-NonCommercialShareAlike-3.0 License, which permits use, distribution and reproduction for non-commercial purposes, provided the original is properly cited and derivative works building on this content are distributed under the same license. 